\title{
Amelioration of inflammatory responses by Socheongryong-Tang, a traditional herbal medicine, in RAW 264.7 cells and rats
}

\author{
SANG MI PARK ${ }^{1 *}$, TAE HOON LEE ${ }^{2 *}$, RONGJIE ZHAO ${ }^{3 *}$, YOUN SOOK KIM $^{4}$, JI YUN JUNG ${ }^{1}$, CHUNG A. PARK $^{1}$ \\ KYUNG HWAN JEGAL ${ }^{1}$, SAE KWANG KU ${ }^{1}$, JAE KWANG KIM ${ }^{1}$, CHUL WON LEE $^{1}$, \\ YOUNG WOO KIM ${ }^{1}$, IL JE CHO ${ }^{1}$, WON G. AN ${ }^{5}$ and SANG CHAN KIM ${ }^{1}$ \\ ${ }^{1}$ Medical Research Center-Globalization of Herbal Formulation, College of Korean Medicine, Daegu Haany University, \\ Gyeongsan 38610; ${ }^{2}$ Department of Biological Sciences, College of Biomedical Sciences and Engineering, Inje University, \\ Gimhae 621-749, Republic of Korea; ${ }^{3}$ Department of Psychopharmacology, School of Mental Health, \\ Qiqihar Medical University, Qiqihar, Heilongjiang 161006, P.R. China; ${ }^{4}$ Department of Biomedical Sciences, \\ School of Medicine; ${ }^{5}$ Division of Pharmacology, School of Korean Medicine, \\ Pusan National University, Yangsan 626-870, Republic of Korea
}

Received February 24, 2017; Accepted January 31, 2018

DOI: $10.3892 /$ ijmm.2018.3465

\begin{abstract}
Socheongryong-Tang (SCRT) is a natural medicine prescription that has been mainly used in East Asia for the treatment of inflammatory disorders, including asthma and allergic rhinitis. The present study evaluated the anti-inflammatory effects of SCRT on lipopolysaccharide (LPS)-stimulated RAW 264.7 cells and in a rat model of carrageenan (CA)-induced paw edema. Levels of tumor necrosis factor- $\alpha$ (TNF- $\alpha)$, interleukin (IL)-1 $\beta$, IL- 6 and prostaglandin $\mathrm{E}_{2}\left(\mathrm{PGE}_{2}\right)$ in the culture supernatant were quantified and nitric oxide (NO) production
\end{abstract}

Correspondence to: Dr Sang Chan Kim, Medical Research Center-Globalization of Herbal Formulation, College of Korean Medicine, Daegu Haany University, Gyeongsan 38610, Republic of Korea

E-mail: sckim@dhu.ac.kr

Dr Won G. An, Division of Pharmacology, School of Korean Medicine, Pusan National University, Yangsan 626-870, Republic of Korea

E-mail:wgan@pusan.ac.kr

${ }^{*}$ Contributed equally

Abbreviations: CA, carrageenan; COX-2, cyclooxygenase; DEXA, dexamethasone; ERK, extracellular signal-regulated kinase; IL, interleukin; iNOS, inducible nitric oxide synthase;

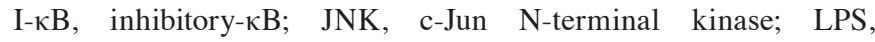
lipopolysaccharide; MAPK, mitogen-activated protein kinase; $N F-\kappa B$, nuclear factor- $\kappa \mathrm{B}$; NO, nitric oxide; $\mathrm{PGE}_{2}$, prostaglandin $\mathrm{E}_{2}$; SCRT, Socheongryong-Tang; TNF- $\alpha$, tumor necrosis factor- $\alpha$; TLR, toll-like receptor; UPLC, ultra performance liquid chromatography

Key words: Socheongryong-Tang, anti-inflammation, inducible nitric oxide synthase, cyclooxygenase- 2 , nuclear factor- $\kappa \mathrm{B}$, mitogen-activated protein kinases, rat paw edema, histological examination was monitored. In addition, the effect of SCRT on the protein expression of nuclear factor- $\kappa \mathrm{B}(\mathrm{NF}-\kappa \mathrm{B})$, mitogen-activated protein kinases (MAPKs), inducible NO synthase (iNOS) and cyclooxygenase-2 (COX-2) was assessed by western blot analysis. Furthermore, the effects of SCRT on acute inflammation in vivo and changes in the histomorphometry and histopathology of paw skin were observed using CA-treated rats. SCRT $(1 \mathrm{mg} / \mathrm{ml})$ inhibited the LPS-induced changes in the protein expression of $\mathrm{NF}-\kappa \mathrm{B}, \mathrm{JNK}, \mathrm{ERK} 1 / 2$, iNOS and $\mathrm{COX}-2$, as well as the production of $\mathrm{NO}, \mathrm{PGE}_{2}$ and cytokines. In the rat paw edema assay, administration of $1 \mathrm{~g} / \mathrm{kg}$ of lyophilized powder obtained from the aqueous extracts of SCRT for 3 consecutive days inhibited the CA-induced increases in skin thickness, mast cell degranulation, and infiltration of inflammatory cells in the ventral and dorsal pedis skin within $4 \mathrm{~h}$. These results demonstrated that SCRT exerts its antiinflammatory activities in LPS-stimulated RAW 264.7 cells through decreasing the production of inflammatory mediators, including $\mathrm{PGE}_{2}$, $\mathrm{NO}$ and cytokines, via suppression of the $\mathrm{NF}-\kappa \mathrm{B}$ and JNK and ERK1/2 signaling pathways. In addition, the data of the CA-induced paw edema indicated an anti-edema effect of SCRT. SCRT $(1 \mathrm{~g} / \mathrm{kg})$ reduced acute edematous inflammation through inhibition of mast cell degranulation and infiltration of inflammatory cells. Therefore, the present study provided scientific evidence for the anti-inflammatory activities of SCRT as well as the underlying mechanisms.

\section{Introduction}

Socheongryong-Tang (SCRT), also known as Xiao-Qing-LongTang or Sho-Seiryu-To, has been commonly used for the treatment of inflammatory diseases, including allergic rhinitis and bronchial asthma, for several centuries in Asian countries (1-3). SCRT is composed of 8 herbal components and is classically administered depending on the specific diseases and symptoms of the patients (4). The major active ingredients of SCRT include liquiritigenin, isoliquiritigenin, glycyrrhizin 
and homogentisic acid, as well as paeoniflorin, kaempferol, gomisin $\mathrm{B}$ and $\mathrm{C}, O$-methoxycinnamaldehyde, higenamine, L-ephedrine and 6-gingerol (2-4).

The inflammatory response is regulated by inflammatory mediators; among these, nitric oxide (NO), prostaglandin $\mathrm{E}_{2}\left(\mathrm{PGE}_{2}\right)$ and cytokines, including tumor necrosis factor- $\alpha$ (TNF- $\alpha$ ), interleukin (IL)-1 $\beta$, and IL-6, are considered to have central roles $(5,6)$. A significant feature of inducible NO synthase (iNOS) and cyclooxygenase-2 (COX-2), which have a major role in the production of $\mathrm{NO}$ and $\mathrm{PGE}_{2}$, is that they are inducible enzymes. $\mathrm{NO}$ is a radical produced from $\mathrm{L}$-arginine through the iNOS, which produces high amounts of NO during inflammation (7-9). Another enzyme involved in the generation of PGs, including $\mathrm{PGH}_{2}$ and $\mathrm{PGE}_{2}$, is COX. Specifically, COX-2 is responsible for mediating inflammation by producing $\mathrm{PGE}_{2}$ induced by factors including lipopolysaccharide (LPS) $(10,11)$. IL-1 $\beta$, which is immunologically associated with TNF- $\alpha$ and IL-6, activates natural killer cells, B cells and T cells and induces fever by acting on the hypothalamus. IL- 6 also has a central role in the acute immune response and increases antibody production by activating lymphocytes. It has also been reported that the levels of this cytokine are always increased in inflammatory lesions $(12,13)$. Furthermore, TNF- $\alpha$ is well known to have key roles in numerous autoimmune diseases and as a primary mediator in inflammatory reactions that occur during immune responses via stimulation of the secretion of other inflammatory cytokines $(12,14)$.

Nuclear factor $\kappa \mathrm{B}(\mathrm{NF}-\kappa \mathrm{B})$ is a transcription factor associated with the transactivation of diverse genes involved in the regulation of tumorigenesis, cellular proliferation and the inflammatory response (15). In addition, mitogen-activated protein kinases (MAPKs) are kinases that are specific to serine and threonine. They include p38 MAPK (p38), extracellular signal-regulated kinases (ERKs) and c-Jun $\mathrm{NH}_{2}$-terminal kinases (JNKs), which have key roles in the modulation of the inflammatory response (16). The signaling pathways of MAPKs may activate NF- $\mathrm{kB}$ and cause the expression of proinflammatory genes (12-14).

Several studies have reported on the anti-allergic activity of SCRT in guinea pig and mouse models of airway inflammation $(1,17,18)$. In addition, SCRT was demonstrated to exhibit an immunomodulaory effect in allergen-sensitized mice (19). However, to the best of our knowledge, the underlying molecular mechanisms of the anti-inflammatory effects of SCRT have remained elusive. Therefore, the present study evaluated the effects of SCRT on the NF- $\mathrm{KB}$ and MAPKs signaling pathways and on NF-kB-dependent induction of inflammatory cytokines, iNOS and COX-2 in RAW 264.7 cells induced with LPS. Furthermore, the effects of SCRT on carrageenan (CA)-induced acute edematous inflammation were examined by histomorphometry and histopathology in vivo. The present study provided a molecular basis for the inhibitory effects of SCRT on inflammatory responses and expanded the current knowledge on the mechanism of action to provide a scientific rationale for the use of SCRT as complementary and alternative medicine.

\section{Materials and methods}

Chemicals and reagents. Five reference standards, namely ephedrine, paeoniflorin, cinnamic acid, glycyrrhizin and
gomisin-A, were obtained from Wako Inc. (Wako, Japan). The purity of the 5 standards was $>98 \%$. Acetonitrile, methanol and other solvents for ultra performance liquid chromatograpy (UPLC) analysis were from J.T. Baker (Avantor, Center Valley, PA, USA). Anti-NF-кB (cat. no. sc-8008), anti-lamin A/C (cat. no. sc-376248), anti-phosphorylated

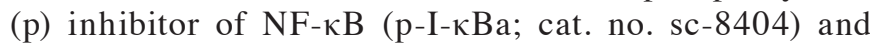
anti-COX-2 (cat. no. sc-19999) antibodies were purchased from Santa Cruz Biotechnology Inc. (Dallas, TX, USA) and JNK (cat. no. 9252), p-JNK (cat. no. 9255), ERK1/2 (cat. no. 9102), p-ERK1/2 (cat. no. 9101), p38 (cat. no. 9212) and p-p38 (cat. no. 9211) antibodies were obtained from Cell Signaling Technology, Inc. (Danvers, MA, USA). Anti- $\beta$-actin (cat. no. sc-58673) and peroxidase-conjugated secondary (cat. no. sc-51625) antibodies were acquired from Santa Cruz Biotechnology Inc. Anti-iNOS antibody (cat. no. MABN527) was acquired from Calbiochem (San Diego, CA, USA). The immunoassay kit (cat. no. KGE004B) for $\mathrm{PGE}_{2}$ was obtained from R\&D Systems (Minneapolis, MN, USA) and ELISA kits for IL-1 $\beta$ (cat. no. EMIL1B), IL-6 (cat. no. EM2IL6) and TNF- $\alpha$ (cat. no. EMTNFA) were purchased from Pierce (Thermo Fisher Scientific, Inc., Waltham, MA, USA). A peroxidase substrate kit (cat. no. SK-4100) and vectastain elite ABC kit (cat. no. PK-6200) were acquired from Vector Lab. Inc. (Burlingame, CA, USA). LPS, sulfanilamide, sodium nitrite, MTT, dexamethasone (DEXA), CA and other chemicals were obtained from Sigma-Aldrich (Merck KGaA, Darmstadt, Germany).

Preparation of SCRT. SCRT $(2 \mathrm{X}, 80 \mathrm{~g})$ consisted of the following medicinal herbs: $12 \mathrm{~g}$ of Ephedrae Herba (Ephedra sinica Stadf.), $12 \mathrm{~g}$ of Paeoniae Radix (Paeonia lactiflora Pall.), $12 \mathrm{~g}$ of Turcz. Ball. Schizandrae Fructus (Schizandra chinensis), $12 \mathrm{~g}$ of Tenore et Breit. Pinelliae Rhizoma (Pinellia ternata), $8 \mathrm{~g}$ of Asiasari Radix (Asarum sieboldii F. Maekawa), $8 \mathrm{~g}$ of Zingiberis Rhizoma (Zingiber officinale Rosc.), $8 \mathrm{~g}$ of Cinnamomi Ramulus (Cinnamomum cassia Blume.) and $8 \mathrm{~g}$ of Glycyrrhizae Radix (Glycyrrhiza glabra L.). All medicinal herbs were purchased from Daewon Pharmacy (Daegu, Korea) and voucher specimens (no. PNU10-28) were deposited in the Herbarium at the School of Korean Medicine, Pusan National University (Busan, Korea). The mixture $(80 \mathrm{~g})$ was extracted with 1.21 of boiling distilled water for at least $3 \mathrm{~h}$, then filtered through filter paper (Hyundai Micro no. 20; Hyundai Pharmaceutical Co., Ltd., Seoul, South Korea) and the filtrate was then lyophilized. The percentage yield of lyophilized SCRT extract was $14.8 \%$. The lyophilized powder of SCRT was dissolved in distilled water immediately prior to use, and then filter-sterilized (Nalgene, Rochester, NY, USA) using a $0.2-\mu \mathrm{m}$ syringe filter to avoid contamination.

Chemical profiling of SCRT by UPLC. The UPLC operating system was equipped with a Waters ACQUITY ${ }^{\mathrm{TM}}$ (Waters Corp., Milford, MA, USA) pump and photodiode array detector. Signal of the detector was indicated using the Empower Data System. The separation was performed using a Waters ACQUITY ${ }^{\mathrm{TM}}$ BEH C $_{18}$ column $(2.1 \times 100 \mathrm{~cm} ; 1.7 \mu \mathrm{m}$ particle size; Waters Corp.). The mobile phase was comprised of $0.1 \%$ formic acid in water and $0.1 \%$ formic acid in acetonitrile with application of gradient elution $(0.4 \mathrm{ml} / \mathrm{min})$. The 
volume for injection was always $2 \mu 1$, the ultraviolet wavelength for detection was $254 \mathrm{~nm}$ and the column temperature was kept at $25^{\circ} \mathrm{C}$. To obtain the chemical profile of SCRT, the lyophilized powder of SCRT aqueous extracts was dissolved in methanol $(10 \mathrm{mg} / \mathrm{ml})$. Prior to UPLC analysis, the sample solution was filtered using a $0.22-\mu \mathrm{m}$ filter. In addition, standard solutions of 5 components, ephedrine, paeoniflorin, cinnamic acid, glycyrrhizin and gomisin-A, were prepared $(1,000 \mu \mathrm{g} / \mathrm{ml}$ in methanol). All solutions were stored at $4^{\circ} \mathrm{C}$.

Cell culture. RAW 264.7 cells (American Type Culture Collection, Manassas, VA, USA) were cultured in Dulbecco's modified Eagle's medium (HyClone; Thermo Fisher Scientific, Inc.) containing $10 \%$ heat-inactivated fetal bovine serum (Sigma-Aldrich; Merck KGaA), $100 \mu \mathrm{g} / \mathrm{ml}$ streptomycin and $100 \mathrm{U} / \mathrm{ml}$ penicillin (Gibco; Thermo Fisher Scientific, Inc.) at $37^{\circ} \mathrm{C}$ in a $5 \% \mathrm{CO}_{2}$ incubator.

MTT assay. To examine the cytotoxicity of SCRT, RAW 264.7 cells $\left(5 \times 10^{4} /\right.$ well) were seeded in a $96-$ well plate. The cells were serum-starved for $16-17 \mathrm{~h}$, after which they were pre-treated with diverse concentrations of SCRT for $1 \mathrm{~h}$, followed by induction with LPS $(1 \mu \mathrm{g} / \mathrm{ml})$ at $37^{\circ} \mathrm{C}$ with $5 \% \mathrm{CO}_{2}$ for an additional $20 \mathrm{~h}$. After incubation, the cells were stained with MTT (4 h, $0.5 \mathrm{mg} / \mathrm{ml})$. The media were then removed and formazan crystals were dissolved by adding dimethyl sulfoxide at $200 \mu \mathrm{l} /$ well. Next, the absorbance was read at $570 \mathrm{~nm}$ with an automated microplate reader (Infinite 200 Pro; Tecan, Männedorf, Switzerland). The viability of cells relative to that of the untreated cells was calculated as follows: Viability $(\%$ of control $)=($ optical density of treated sample $) /($ optical density of untreated control) x $100 \%$.

Measurement of NO. According to previously established procedures (20-23), RAW 264.7 cells $\left(5 \times 10^{5}\right.$ cells $\left./ \mathrm{ml}\right)$ were cultured for $\sim 16 \mathrm{~h}$ and then treated with diverse concentrations of SCRT for $1 \mathrm{~h}$, followed by induction with LPS $(1 \mu \mathrm{g} / \mathrm{ml})$. Cells were then incubated in a $5 \% \mathrm{CO}_{2}$ incubator $\left(37^{\circ} \mathrm{C}\right)$ for $20 \mathrm{~h}$, after which the culture supernatants were collected. NO was measured by reaction with $100 \mu \mathrm{l}$ Griess reagent $[0.1 \%$ $\mathrm{N}$-(1-naphthy)-ethylenediamine dihydrochloride $+1 \%$ sulfanilamide in the 5\% phosphoric acid; Hoffmann-La Roche AG, Basel, Switzerland] with $100 \mu 1$ supernatant of cells at $25^{\circ} \mathrm{C}$ for $15 \mathrm{~min}$. The absorbance was read at $540 \mathrm{~nm}$ with a microplate reader (Tecan). The standard curve was drawn using $\mathrm{NaNO}_{2}$.

$I L-1 \beta, I L-6, T N F-\alpha$ and $P G E_{2}$ assays. RAW 264.7 cells at a concentration of $5 \times 10^{5}$ cells $/ \mathrm{ml}$ were cultured for $16 \mathrm{~h}$, after which they were pre-treated with diverse concentrations of SCRT for $1 \mathrm{~h}$, and then stimulated with $1 \mu \mathrm{g} / \mathrm{ml} \mathrm{LPS}$. The culture supernatants were collected at $20 \mathrm{~h}$ after LPS stimulation and levels of IL-1 $\beta$, IL- 6 , TNF- $\alpha$ and PGE $_{2}$ were quantified using a microplate reader (Tecan).

Preparation of whole-cell lysates and nuclear extracts. To prepare whole-cell lysates, control and SCRT-treated RAW 264.7 cells were harvested by centrifugation and rinsed with PBS. Washed pellets of cells were resuspended in lysis buffer [250 mM NaCl, $50 \mathrm{mM}$ 4-(2-hydroxyethyl)-1-piperazineethanesulfonic acid (HEPES; pH 7.0), 0.1\% Nonidet P
(NP)-40, 5 mM EDTA, $1 \mathrm{mM}$ phenylmethylsulfonyl fluoride, $0.5 \mathrm{mM}$ dithiothreitol (DTT), $0.5 \mathrm{mM}$ sodium orthovanadate and $5 \mathrm{mM} \mathrm{NaF}$ ] containing $5 \mu \mathrm{g} / \mathrm{ml}$ each of aprotinin and leupeptin, and then incubated at $4^{\circ} \mathrm{C}$ for $20 \mathrm{~min}$. Microcentrifugation was performed to remove cell debris, accomplished by rapid freezing of supernatants. To prepare nuclear extracts, cells were then swollen by adding lysis buffer $[10 \mathrm{mM} \mathrm{KCl}$, protease inhibitor cocktail, $1 \mathrm{mM}$ DTT, $10 \mathrm{mM}$ HEPES (pH 7.9), $1.5 \mathrm{mM}$ $\mathrm{MgCl}_{2}$ and $0.2 \% \mathrm{NP}-40$ (Roche Diagnostics, Indianapolis, IN, USA)]. The samples were then incubated on ice for $10 \mathrm{~min}$ and centrifuged at $4^{\circ} \mathrm{C}$ for $5 \mathrm{~min}$. Pellets containing the nuclei were suspended in $50 \mu \mathrm{l}$ buffer containing $1.5 \mathrm{mM} \mathrm{MgCl}$, $20 \mathrm{mM}$ HEPES (pH 7.9), protease inhibitor cocktail, $420 \mathrm{mM}$ $\mathrm{NaCl}, 1 \mathrm{mM}$ DTT and $20 \%$ glycerol, followed by incubation on a shaker at $4^{\circ} \mathrm{C}$ for $30 \mathrm{~min}$. Finally, samples were centrifuged $(16,000 \mathrm{x} \mathrm{g})$ for $10 \mathrm{~min}$. A Bradford assay (Bio-Rad Laboratories, Inc., Hercules, CA, USA) was applied for the determination of protein concentrations.

Western blot analysis. Protein from untreated or treated cell extracts $(30 \mu \mathrm{g})$ was subjected to $8 \%$ SDS-PAGE, after which they were electroblotted onto nitrocellulose membranes (Thermo Fisher Scientific, Inc.). Samples were then blocked in $5 \%$ skim milk in $0.1 \%$ Tween-20/Tris-buffered saline (TTBS) at room temperature for $1 \mathrm{~h}$, incubated overnight in the primary antibody solutions (1:1,000 dilution) at $4^{\circ} \mathrm{C}$. The blots were subsequently rinsed with TTBS, stirred with a dilute solution of horseradish peroxidase-conjugated antibody $(1: 1,000)$ at $25^{\circ} \mathrm{C}$ for $1 \mathrm{~h}$, and then washed 3 times with TTBS. Western blot detection reagents (enhanced chemiluminescence; GE Healthcare, Little Chalfont, UK) were utilized to develop the blots.

CA-induced paw edema. Paw edema experiments were performed according to previously established procedures (20-23). All animal procedures were performed in accordance with the national regulations regarding the welfare and usage of laboratory animals and protocols were approved by the Institutional Animal Care and Use Committee of Daegu Haany University (Gyeongsan, South Korea; approval no. DHU2011-020). Male Sprague Dawley rats (age, 4 weeks; weight, 80-100 g) were obtained from Samtako Co. (Osan, South Korea) and acclimatized for one week. The animals were reared in a pathogen-free environment at $20-23^{\circ} \mathrm{C}$ under a $12-\mathrm{h}$ light/dark cycle and a relative humidity of $50 \%$ with commercial chow (Nestle Purina PetCare Ltd., Seoul, South Korea) and water provided ad libitum. Rats $(\mathrm{n}=25)$ were randomly divided into 5 groups that consisted of 5 animals each. SCRT was administered to rats by oral gavage at different doses $(0.3$ and $1.0 \mathrm{~g} / \mathrm{kg} / \mathrm{day}$ ) for 3 consecutive days. An anti-inflammatory drug, DEXA, was applied as a positive control. To cause acutephase inflammation, rats received a subcutaneous injection of a CA solution ( $1 \%$ in saline; $0.1 \mathrm{ml} / \mathrm{rat}$ ) into the right hind paw at $1 \mathrm{~h}$ after SCRT or vehicle treatment. The paw volumes were measured for $4 \mathrm{~h}$ after injection with 1-h intervals. The paw volume was recorded using a plethysmometer (Ugo Basile, Varese, Italy).

Histological examination. The paw skins (ventrum and dorsum) were separated and fixed in neutral buffered formalin 
(10\%), subsequently embedded in paraffin, sliced (3-4 $\mu \mathrm{m})$ and stained using hematoxylin and eosin for histopathological profiles and toluidine blue for mast cells. To observe the changes induced by CA treatment in greater detail, the thicknesses of dorsal and ventral skins (from the epidermis to the dermis, excluding keratin layers; $\mu \mathrm{m} / \mathrm{paw})$ were measured using an automated image analyzer (DMI-300; DMI, Daegu, South Korea) and a light microscope (Nikon, Tokyo, Japan) under 40x magnification, and the mast and infiltrated inflammatory cells were counted by an automated image analyzer and denoted as cells $/ \mathrm{mm}^{2}$ of dermis under 200x magnification.

Statistical analysis. All values are expressed as the mean \pm standard deviation. Multiple-comparisons tests were performed for different dose groups. Levene's test was used to test for homogeneity in variance. If the Levene test indicated an insignificant deviation from variance homogeneity, the results were analyzed by one way analysis of variance, followed by the least-significant differences multi-comparison test assess significant differences between pairs of groups. For non-parametric analysis, the Kruskal-Wallis H test was used. When a significant difference was indicated by a Kruskal-Wallis H test, the Mann-Whitney U test was performed to identify specific pairs that differed significantly. SPSS (version 14.0K; SPSS, Inc., Chicago, IL, USA) was applied for statistical analyses. Differences were considered significant at $\mathrm{P}<0.05$.

\section{Results}

Analysis of SCRT. Determination of 5 markers, ephedrine, paeoniflorin, cinnamic acid, glycyrrhizin, and gomisin-A, in SCRT was established using an UPLC system. The contents of the 5 components in SCRT were calculated from the standard curve (Table I and Fig. 1).

SCRT inhibits LPS-stimulated $\mathrm{NO}$ and $P G E_{2}$ production and reduction in cell viability. To measure the inhibitory effects of SCRT on LPS-stimulated NO production in RAW 264.7 cells, $0.25,0.5$ and $1 \mathrm{mg} / \mathrm{ml} \mathrm{SCRT} \mathrm{were} \mathrm{analyzed.} \mathrm{Compared} \mathrm{with}$ the control, treatment with LPS $(1 \mu \mathrm{g} / \mathrm{ml}$ for $20 \mathrm{~h})$ significantly increased NO production. However, treatment with SCRT significantly inhibited LPS-stimulated NO production (Fig. 2A, left). SCRT $(0.25-1 \mathrm{mg} / \mathrm{ml})$ in the absence of LPS did not change the basal levels of NO production in RAW 264.7 cells (Fig. 2A, right). In addition, the effects of SCRT on LPS-stimulated $\mathrm{PGE}_{2}$ production were also measured. When compared with the control, LPS treatment significantly increased $\mathrm{PGE}_{2}$ production. However, treatment with SCRT significantly suppressed LPS-stimulated $\mathrm{PGE}_{2}$ production (Fig. 2B). Furthermore, the possible cytotoxic effects of SCRT in RAW 264.7 cells were examined using an MTT assay. The viability of cells was not affected by SCRT treatment, at least up to the SCRT concentration of $1 \mathrm{mg} / \mathrm{ml}$ (Fig. 2C).

SCRT inhibits LPS-stimulated iNOS and COX-2 expression. To examine whether the inhibitory effects of SCRT were associated with the expression of iNOS and COX-2, western blot analysis was performed. The protein levels of iNOS and COX-2 were highly upregulated in response to LPS, while treatment
Table I. Contents of 5 marker compounds in SocheongryongTang as determined by ultra performance liquid chromatography $(n=3)$.

\begin{tabular}{lc}
\hline Compound & Content $(\mu \mathrm{g} / \mathrm{ml})$ \\
\hline Ephedrine & $21.7 \pm 0.41$ \\
Paeoniflorin & $10.7 \pm 1.09$ \\
Cinnamic acid & $0.19 \pm 0.02$ \\
Glycyrrhizin & $2.50 \pm 0.03$ \\
Gomisin-A & $1.97 \pm 0.08$
\end{tabular}

with SCRT significantly inhibited the upregulation of iNOS and COX-2 in a dose-dependent manner (Fig. 3A and B).

SCRT reduces LPS-inducible IL-1 $\beta, I L-6$ and $T N F-\alpha$ production. The present study investigated the effects of SCRT on LPS-inducible IL-1 $\beta$, IL- 6 and TNF- $\alpha$ production by ELISA. When compared with the control, treatment with LPS $(1 \mu \mathrm{g} / \mathrm{ml}$ for $20 \mathrm{~h})$ significantly increased the production of IL-1 $\beta$, IL- 6 and TNF- $\alpha(\mathrm{P}<0.01)$. However, treatment with SCRT significantly inhibited LPS-inducible IL-1 $\beta$, IL-6 and TNF- $\alpha$ production in a dose-dependent manner (Fig. 4).

SCRT inhibits LPS-stimulated activation of NF- $\kappa B$. To examine whether the reduction of nuclear translocation of NF- $\kappa B$ (p65) by SCRT was due to the inhibition of $\mathrm{p}-\mathrm{I}-\kappa \mathrm{B} \alpha$, western blot analysis was performed to evaluate levels of $\mathrm{p}-\mathrm{I}-\kappa \mathrm{B} \alpha$ and nuclear NF- $\kappa \mathrm{B}$ (p65). Treatment with LPS for

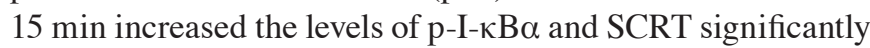
blocked this LPS-stimulated increase (Fig. 5A). In addition, NF- $\kappa B$ (p65) was accumulated in the nucleus after treatment with LPS for $15 \mathrm{~min}$, which was significantly inhibited by pretreatment with SCRT (Fig. 5B).

Inhibitory effects of SCRT on LPS-stimulated phosphorylation of MAPKs. To examine the molecular targets of SCRT and associated signaling pathways, the effects of SCRT on LPS-stimulated phosphorylation of JNK, ERK1/2 and p38 in RAW 264.7 cells were evaluated. As presented in Fig. 6, the phosphorylation of JNK, ERK1/2 and p38 was significantly increased after LPS treatment $(1 \mu \mathrm{g} / \mathrm{ml})$ for $15 \mathrm{~min}$. However, treatment with SCRT $(1 \mathrm{mg} / \mathrm{ml})$ significantly decreased the phosphorylation of JNK and ERK1/2, whereas the phosphorylation of p38 was unaffected.

SCRT reduces CA-induced paw edema, as well as iNOS and COX-2 protein expression in paw tissues. In accordance with the results of previous studies (20-23), the present results indicated that CA injection significantly increased the paw swelling relative to the control group within $4 \mathrm{~h}$. However, treatment with DEXA (positive control; $1 \mathrm{mg} / \mathrm{kg} /$ day, per os) resulted in a significant decrease in edema formation relative to that in the CA group $(\mathrm{P}<0.01)$. Treatment with SCRT $(0.3$ and $1 \mathrm{~g} / \mathrm{kg} / \mathrm{day}$, per os, 3 days) also significantly decreased paw edema volumes within $4 \mathrm{~h}$ (Fig. 7A). CA significantly increased the expression of iNOS and COX-2 protein relative 

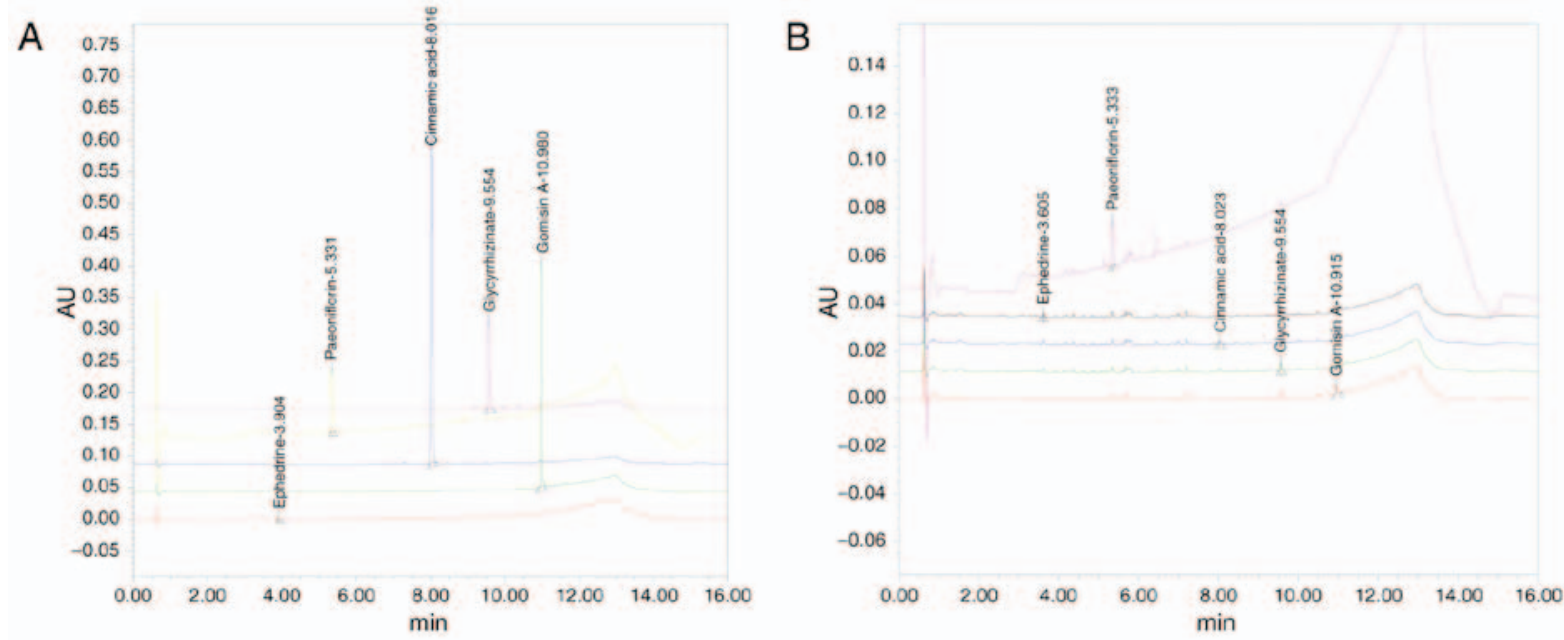

Figure 1. UPLC chromatogram of 5 marker compounds in SCRT. (A) UPLC chromatogram of commercial standard compounds. (B) UPLC chromatogram of 5 marker compounds in SCRT. The chromatograms were obtained at $254 \mathrm{~nm}$. UPLC, ultra performance liquid chromatography; AU, absorbance units; SCRT, Socheongryong-Tang.
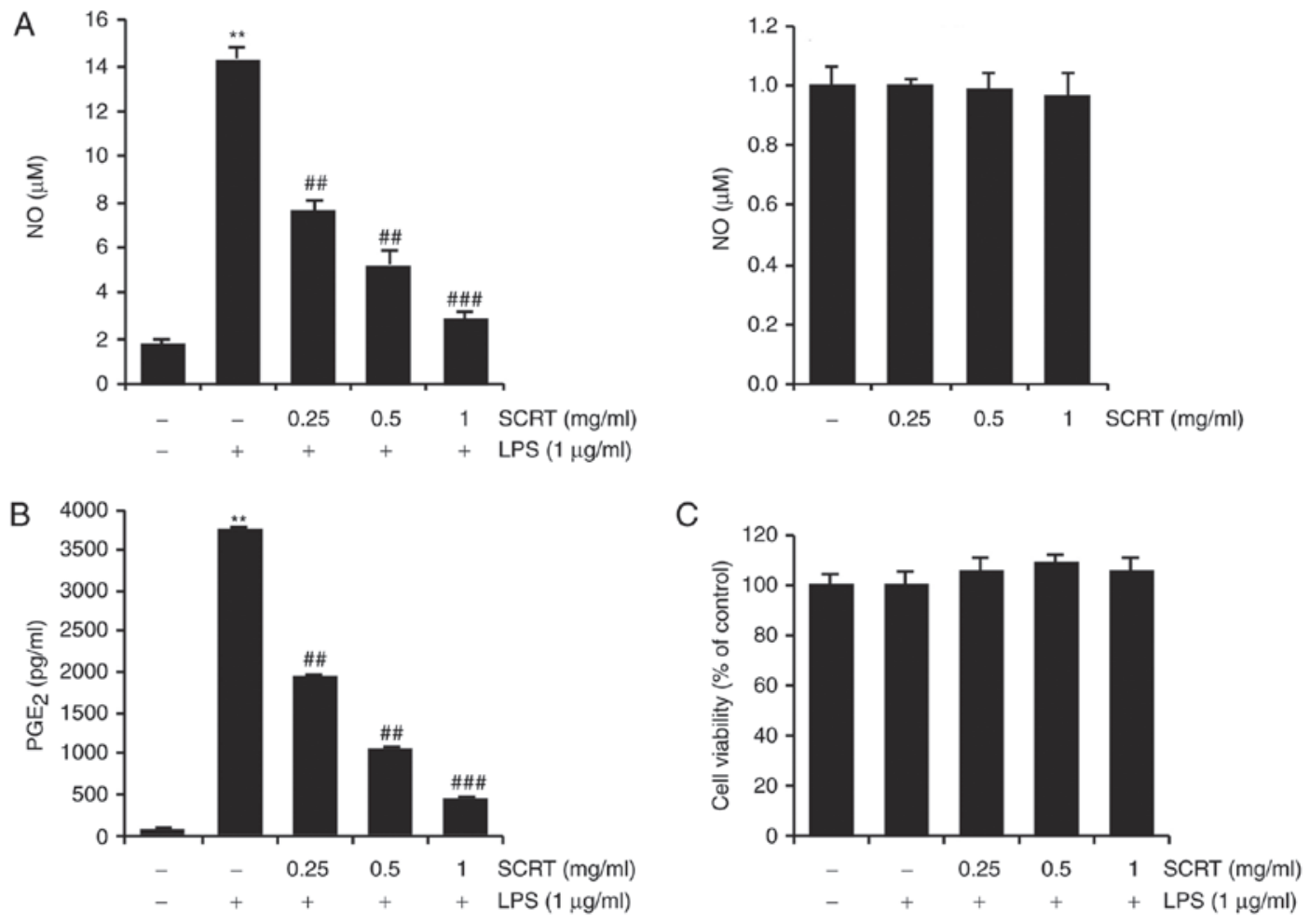

Figure 2. Effects of SCRT on the production of (A) NO and (B) $\mathrm{PGE}_{2}$, and on (C) the viability of LPS-stimulated RAW 264.7 cells. Cells at $5 \times 10^{5} / \mathrm{ml}$ were treated with different concentrations of SCRT $(0.25,0.5$ or $1 \mathrm{mg} / \mathrm{ml})$ for $1 \mathrm{~h}$, followed by induction with $1 \mu \mathrm{g} / \mathrm{ml} \mathrm{LPS}$ for $20 \mathrm{~h}$. Control groups were incubated with vehicle instead. The concentrations of $\mathrm{NO}$ and $\mathrm{PGE}_{2}$ in the culture supernatant were determined. In addition, the effects of SCRT on the viability of the cells were determined by an MTT assay. Values are expressed as the mean \pm standard deviation of 3 replicates for each condition. ${ }^{* *} \mathrm{P}<0.01$ vs. vehicle-treated control; ${ }^{\# \#} \mathrm{P}<0.01,{ }^{\# \#} \mathrm{P}<0.001$ vs. LPS only group. SCRT, Socheongryong-Tang; LPS, lipopolysaccharide; $\mathrm{NO}$, nitric oxide; $\mathrm{PGE}_{2}$, prostaglandin $\mathrm{E}_{2}$.

to the control in the paw tissues. However, DEXA significantly decreased the expression of iNOS and COX-2 protein. In addition, SCRT $(1 \mathrm{~g} / \mathrm{kg})$ also significantly decreased the expression of iNOS and COX-2 protein $(\mathrm{P}<0.001$; Fig. 7B).

Histological examination. Representative histological profiles of the dorsal and ventral pedis skins observed after CA and DEXA or SCRT treatment are presented in Figs. 8 and 9, respectively. In addition, the histomorphometrical measurements of the dorsal and ventral pedis skins are listed in Table II. The thicknesses of the dorsal and ventral pedis skins at $4 \mathrm{~h}$ after CA injection were increased by 152.50 and $132.14 \%$, respectively, as compared with those in the control group. In addition, the thickness of the dorsal pedis skin in rats treated with DEXA and SCRT at $0.3 \mathrm{~g} / \mathrm{kg}$ (low dose) and $1 \mathrm{~g} / \mathrm{kg}$ (high dose) was decreased by $44.80,18.67$ and $31.05 \%$, respectively, and that of the ventral pedis skin was decreased by $33.97,5.27$ and $19.73 \%$, respectively, compared with that 
A
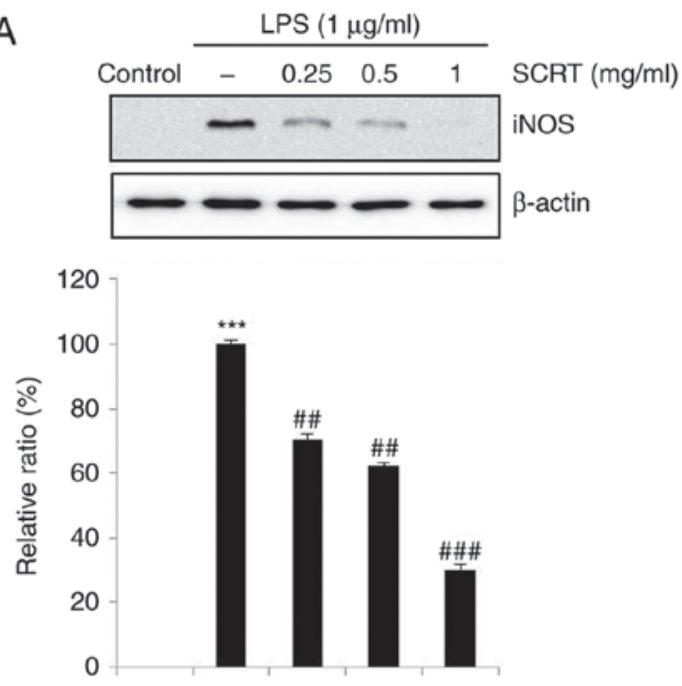

B
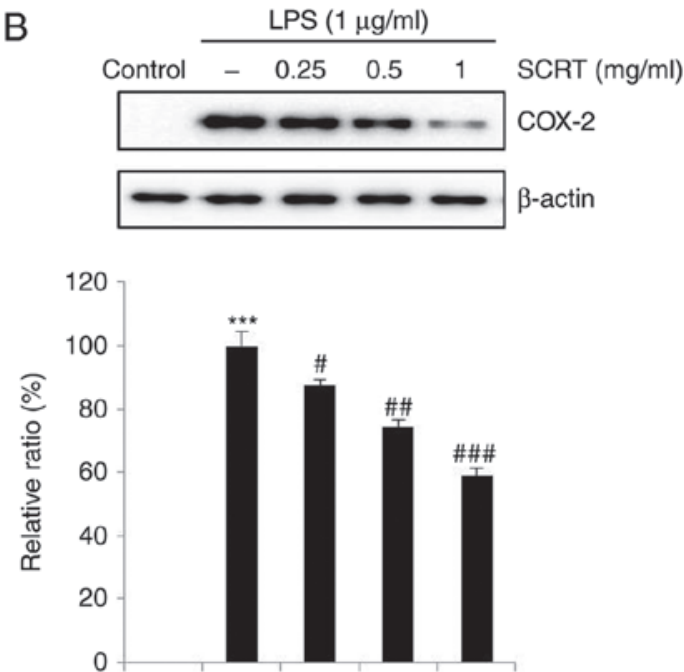

Figure 3. Inhibitory effects of SCRT on LPS-induced expression of (A) iNOS and (B) COX-2. RAW 264.7 cells (5x10 cells/ml) were treated with different concentrations of SCRT $(0.25,0.5$ and $1 \mathrm{mg} / \mathrm{ml})$ for $1 \mathrm{~h}$, followed by induction with $1 \mu \mathrm{g} / \mathrm{ml}$ of LPS for $20 \mathrm{~h}$. Control cells were incubated with vehicle alone. The protein levels of COX-2 and iNOS were examined by western blot analysis. $\beta$-Actin was used as a control. The expression levels of iNOS and COX-2 relative to $\beta$-actin were quantified by densitometry. Values are expressed as the mean \pm standard deviation of 3 replicates for each condition. ${ }^{* * *} \mathrm{P}<0.001 \mathrm{vs}$. vehicle-treated control; ${ }^{\#} \mathrm{P}<0.05,{ }^{\# \#} \mathrm{P}<0.01,{ }^{\# \# \#} \mathrm{P}<0.001$ vs. LPS only group. iNOS, inducible nitric oxide synthase; COX, cyclooxygenase; SCRT, SocheongryongTang; LPS, lipopolysaccharide.
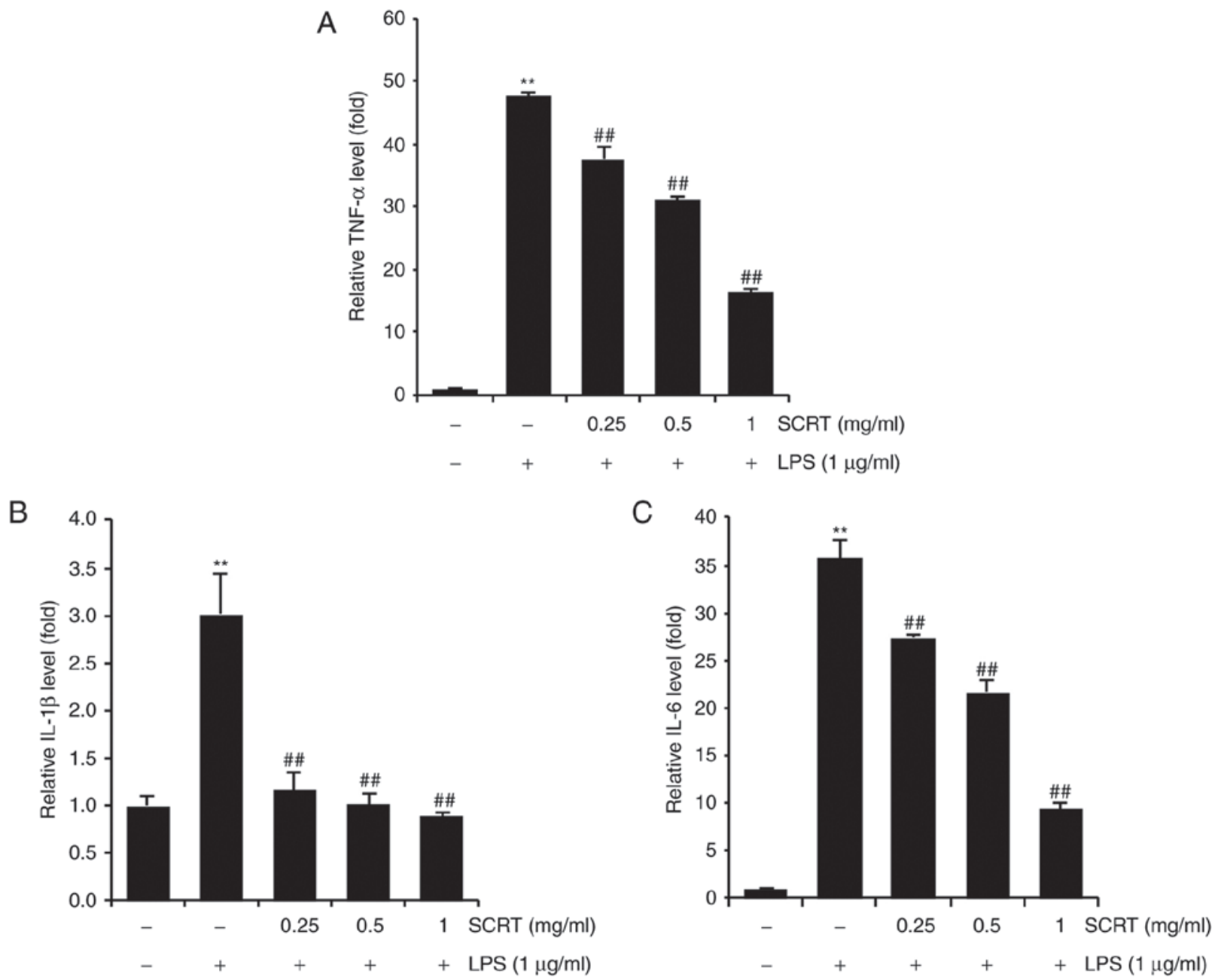

Figure 4. Inhibitory effects of SCRT on LPS-induced production of the pro-inflammatory cytokines (A) TNF- $\alpha$, (B) IL-1 $\beta$ and (C) IL-6 in RAW 264.7 cells. The cells $\left(5 \times 10^{5} / \mathrm{ml}\right)$ were treated with SCRT $(0.25,0.5$ and $1 \mathrm{mg} / \mathrm{ml})$ for $1 \mathrm{~h}$, followed by induction with $1 \mu \mathrm{g} / \mathrm{ml} \mathrm{LPS} \mathrm{for} 20 \mathrm{~h}$. Control cells were incubated with vehicle alone. The levels of the pro-inflammatory cytokines were measured using ELISA. Values are expressed as the mean \pm standard deviation of 3 replicates for each condition. ${ }^{* *} \mathrm{P}<0.01$ vs. vehicle-treated control; ${ }^{\# \#} \mathrm{P}<0.01$ vs. LPS only group. SCRT, Socheongryong-Tang; LPS, lipopolysaccharide; TNF, tumor necrosis factor; IL, interleukin. 
A
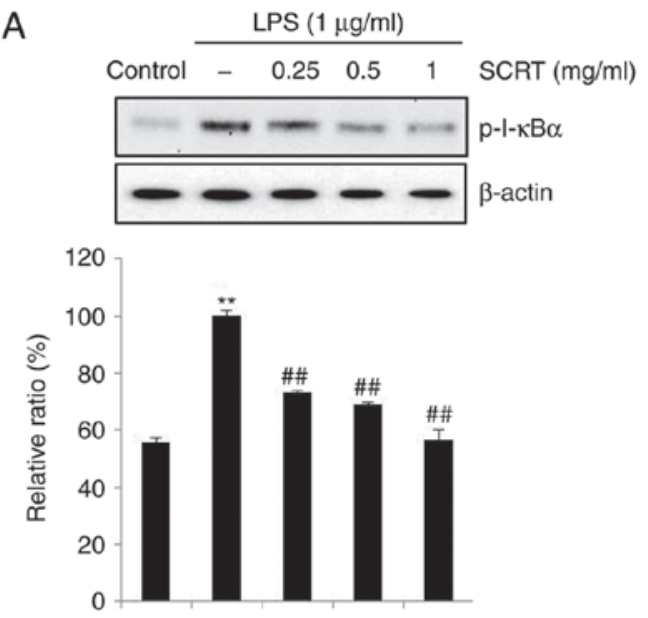

B
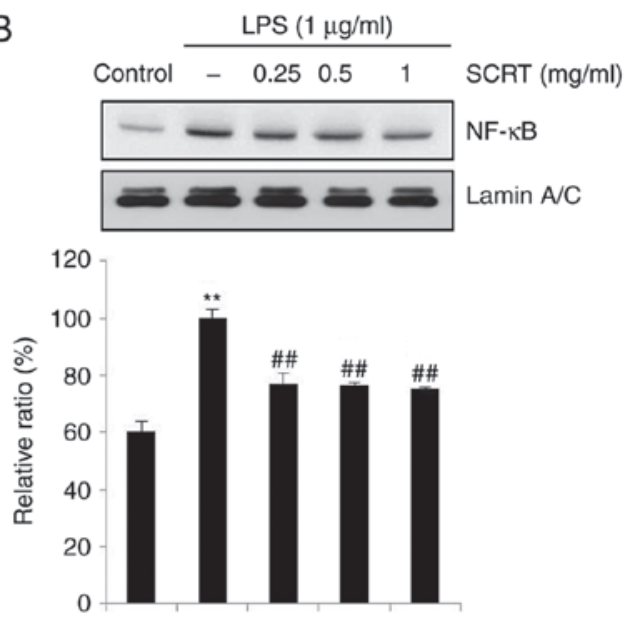

Figure 5. Inhibitory effects of SCRT on the LPS-induced activation of (A) p-I-kB $\alpha$ and (B) nuclear NF-kB (p65). RAW 264.7 cells at a concentration of $5 \times 10^{5} / \mathrm{ml}$ were treated with SCRT $(0.25,0.5$ or $1 \mathrm{mg} / \mathrm{ml})$ for $1 \mathrm{~h}$ and then with LPS $(1 \mu \mathrm{g} / \mathrm{ml})$ for $15 \mathrm{~min}$. Control cells were treated with vehicle only. Western

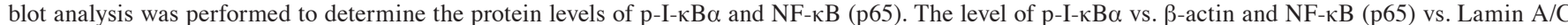
were quantified by densitometry. Values are expressed as the mean \pm standard deviation of 3 replicates for each condition. ${ }^{* * *} \mathrm{P}<0.01$ vs. vehicle-treated control;

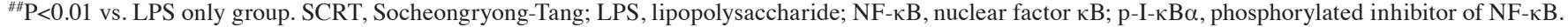
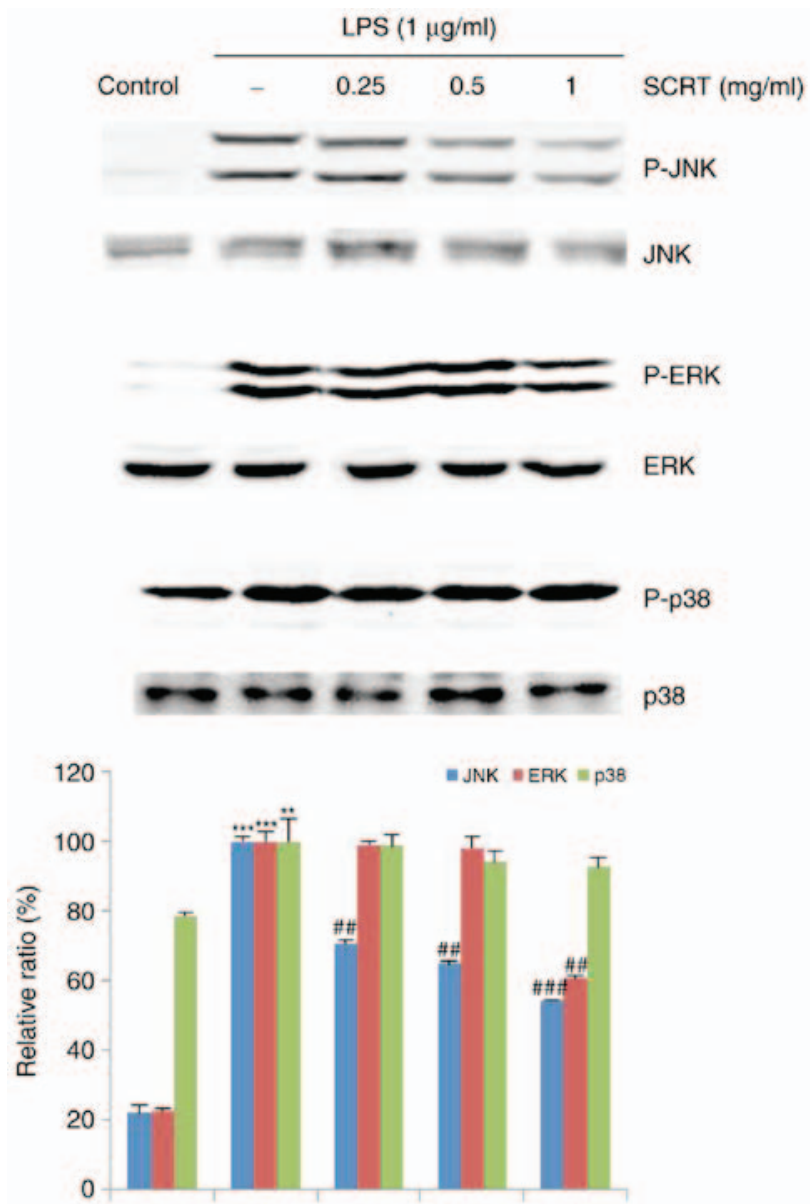

Figure 6. Inhibitory effects of SCRT on the phosphorylation of mitogenactivated protein kinases (JNK, ERK and p38) in LPS-stimulated RAW 264.7 cells. The cells were treated with the indicated concentrations of SCRT for $1 \mathrm{~h}$, followed by induction with $1 \mu \mathrm{g} / \mathrm{ml}$ LPS for $15 \mathrm{~min}$. Western blot analysis was performed using anti-phosphokinase antibodies for cell extract analysis. Phosphorylated JNK, ERK1/2 and p38 vs. total JNK, ERK1/2 and p38 were measured via densitometry. Values are expressed as the mean \pm standard deviation of 3 replicates for each condition. ${ }^{* *} \mathrm{P}<0.01,{ }^{* * *} \mathrm{P}<0.001$ vs. vehicle-treated control; ${ }^{\# \#} \mathrm{P}<0.01,{ }^{\# \# "} \mathrm{P}<0.001$ vs. LPS only group. SCRT, Socheongryong-Tang; LPS, lipopolysaccharide; JNK, c-Jun N-terminal kinase; p-ERK, phosphorylated extracellular signal-regulated kinase.

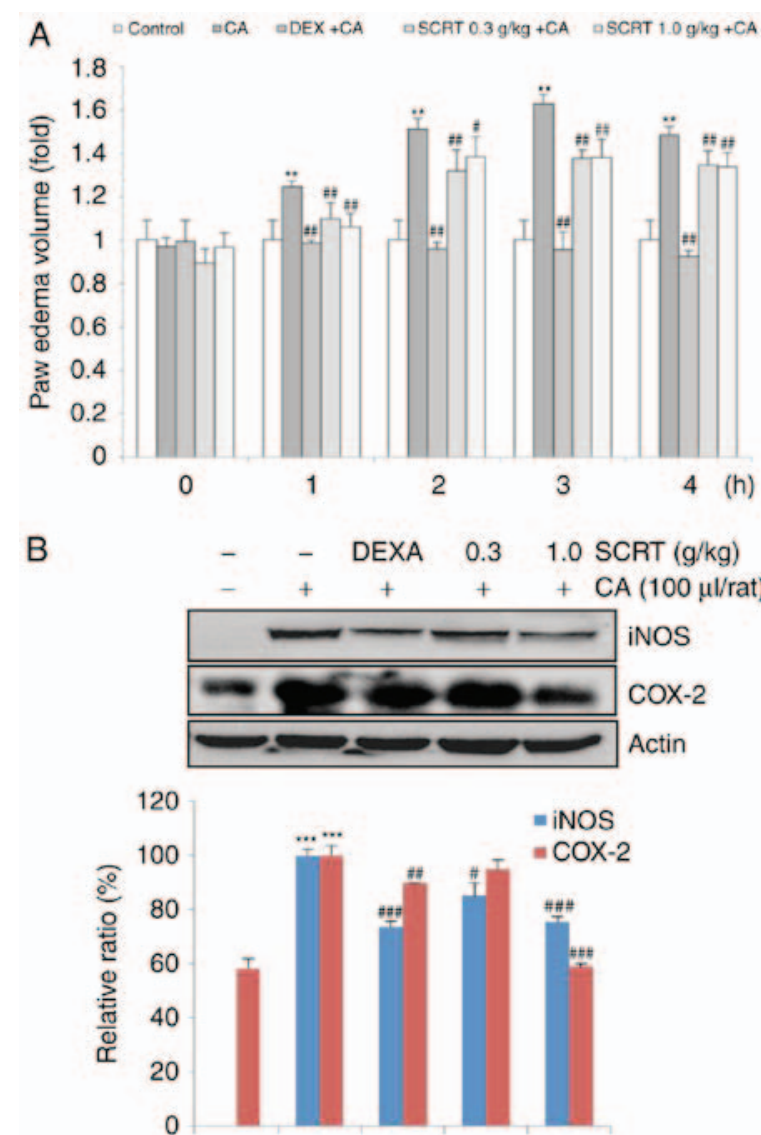

Figure 7. Effects of SCRT on CA-induced paw edema volume and expression of iNOS and COX-2 by CA in the paw tissues. Rats were orally pretreated with DEXA ( $1 \mathrm{mg} / \mathrm{kg}$, p.o., 3 days) or SCRT ( 0.3 or $1 \mathrm{~g} / \mathrm{kg}$, p.o., 3 days) and subcutaneously injected with $1 \% \mathrm{CA}(100 \mu \mathrm{l} / \mathrm{rat}$, dissolved in sterilized saline). (A) The volume of paw swelling was recorded at $0-4 \mathrm{~h}$ after CA injection. (B) The protein from paw tissue samples of rats at $4 \mathrm{~h}$ after CA injection was isolated and the expression of iNOS and COX-2 was determined using western blot analysis. $\beta$-actin was used as a loading control. Values are expressed as the mean \pm standard deviation of 3 replicates for each condition. ${ }^{* * *} \mathrm{P}<0.01,{ }^{* * * *} \mathrm{P}<0.001$ vs. vehicle-treated control; ${ }^{\#} \mathrm{P}<0.05,{ }^{\# \#} \mathrm{P}<0.01,{ }^{\# \# "} \mathrm{P}<0.001$ vs. CA only group. SCRT, Socheongryong-Tang; LPS, lipopolysaccharide; DEXA, dexamethasone; CA, carrageenan; iNOS, inducible nitric oxide synthase; COX, cyclooxygenase; p.o., per os. 

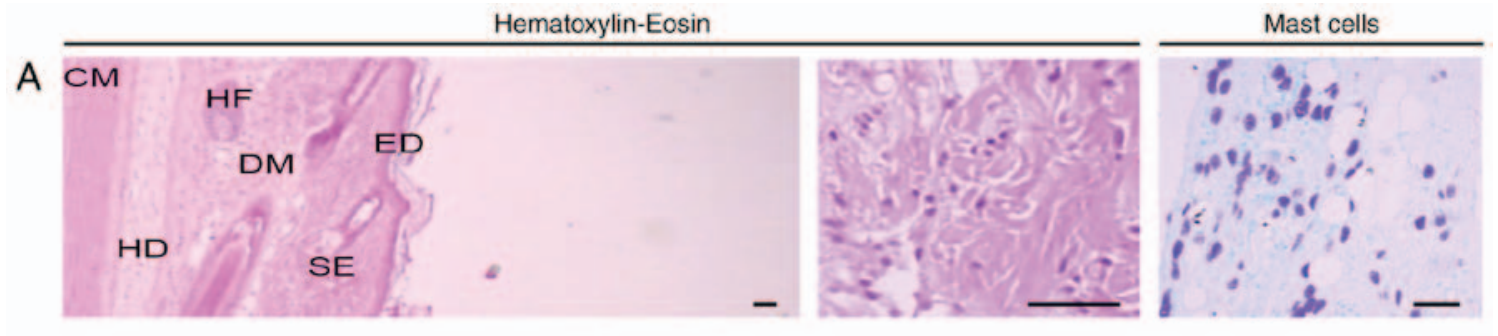

$\mathrm{B}$
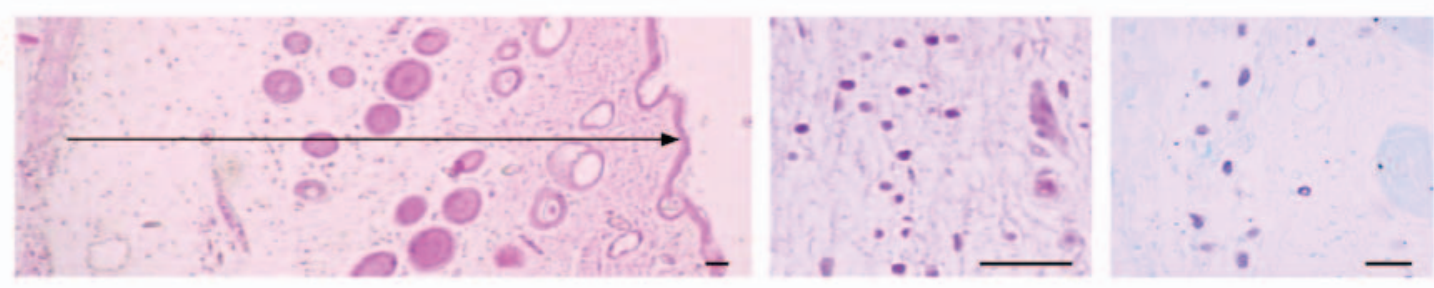

C
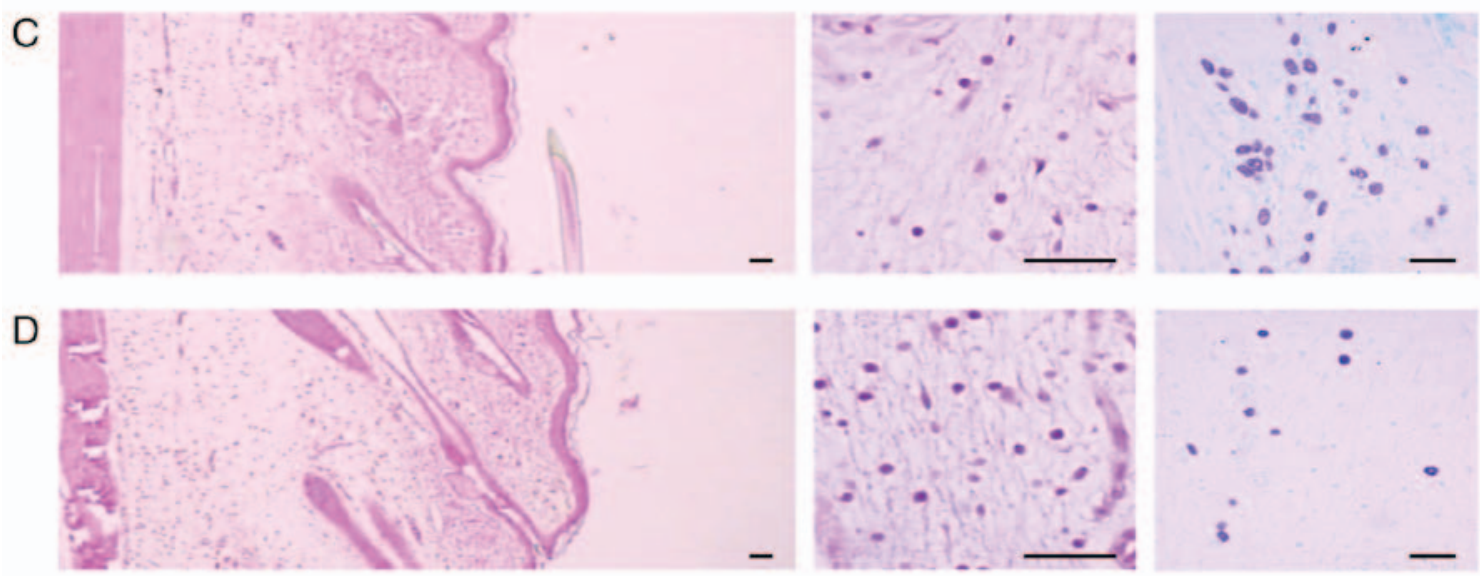

$\mathrm{E}$
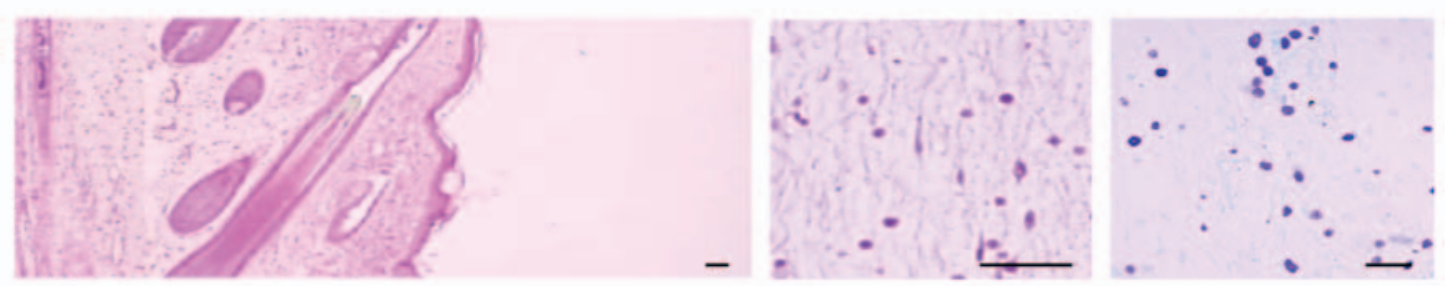

Figure 8. Histological images of the dorsal pedis skin. Tissue sections from the dorsal pedis of the (A) Control, (B) CA, (C) CA and dexamethasone-treated, (D) CA and SCRT (0.3 g/kg)-treated and the (E) CA and SCRT $(1.0 \mathrm{~g} / \mathrm{kg})$-treated rats were stained with hematoxylin and eosin or toluidine blue for histopathological examination. The arrow indicates the total thickness and scale bars indicate $40 \mu \mathrm{m}$. CM, cutaneous muscle; DM, dermis; ED, epidermis; HD, hypodermis; HF, hair follicle; SE, sebaceous gland; SCRT, Socheongryong-Tang; LPS, lipopolysaccharide.

Table II. Changes in the histomorphometrical parameters of paw skins.

\begin{tabular}{|c|c|c|c|c|c|c|}
\hline \multirow[b]{2}{*}{ Group } & \multicolumn{3}{|c|}{ Dorsal pedis skin } & \multicolumn{3}{|c|}{ Ventral pedis skin } \\
\hline & $\begin{array}{c}\text { Total } \\
\text { thickness }(\mu \mathrm{m})\end{array}$ & $\begin{array}{l}\text { IF cell number } \\
\left(\text { cells } / \mathrm{mm}^{2}\right)\end{array}$ & $\begin{array}{l}\text { Mast cell } \\
\text { number } \\
\left(\text { cells } / \mathrm{mm}^{2}\right)\end{array}$ & $\begin{array}{l}\text { Total thickness } \\
\qquad(\mu \mathrm{m})\end{array}$ & $\begin{array}{c}\text { IF cell } \\
\text { number } \\
\left(\text { cells } / \mathrm{mm}^{2}\right)\end{array}$ & $\begin{array}{c}\text { Mast cell } \\
\text { number } \\
\left(\text { cells } / \mathrm{mm}^{2}\right)\end{array}$ \\
\hline Control & $937.49 \pm 221.08$ & $28.60 \pm 11.80$ & $58.20 \pm 9.98$ & $595.58 \pm 53.73$ & $20.20 \pm 5.89$ & $35.00 \pm 5.10$ \\
\hline CA & $2,367.14 \pm 369.77^{\mathrm{a}}$ & $288.60 \pm 17.64^{\mathrm{a}}$ & $19.40 \pm 2.30^{\mathrm{a}}$ & $1,382.58 \pm 165.53^{\mathrm{a}}$ & $473.60 \pm 45.64^{\mathrm{b}}$ & $12.00 \pm 2.35^{\mathrm{a}}$ \\
\hline Dexamethasone & $1,306.65 \pm 98.70^{\mathrm{c}, \mathrm{d}}$ & $113.20 \pm 24.79^{\mathrm{a}, \mathrm{c}}$ & $40.00 \pm 10.98^{\mathrm{a}, \mathrm{c}}$ & $912.94 \pm 175.95^{\mathrm{a}, \mathrm{c}}$ & $197.40 \pm 17.04^{\mathrm{b}, \mathrm{e}}$ & $27.80 \pm 4.71^{\mathrm{c}, \mathrm{d}}$ \\
\hline $\operatorname{SCRT}(0.3 \mathrm{~g} / \mathrm{kg})$ & $1,925.25 \pm 217.35^{a, c}$ & $258.80 \pm 38.32^{\mathrm{a}}$ & $22.40 \pm 6.91^{\mathrm{a}}$ & $1,309.70 \pm 162.60^{\mathrm{a}}$ & $412.80 \pm 55.88^{\mathrm{b}}$ & $11.00 \pm 2.55^{\mathrm{a}}$ \\
\hline $\operatorname{SCRT}(1 \mathrm{~g} / \mathrm{kg})$ & $1,632.05 \pm 86.02^{\mathrm{a}, \mathrm{c}}$ & $173.40 \pm 16.70^{\mathrm{a}, \mathrm{c}}$ & $40.80 \pm 7.69^{\mathrm{a}, \mathrm{c}}$ & $1,109.76 \pm 108.75^{\mathrm{a}, \mathrm{c}}$ & $334.80 \pm 38.34^{\mathrm{b}, \mathrm{e}}$ & $20.60 \pm 6.31^{\mathrm{a}, \mathrm{c}}$ \\
\hline
\end{tabular}

Values are expressed as the skin index as a mean \pm standard deviation of 5 rat hind paws. ${ }^{a} \mathrm{P}<0.01$ compared with control group by the LSD test. ${ }^{\mathrm{b}} \mathrm{P}<0.01$ as compared with the control group by the MW test. ${ }^{\mathrm{C}} \mathrm{P}<0.01$ compared with the CA group by the LSD test. ${ }^{\mathrm{d}} \mathrm{P}<0.05$ compared with the control group by the LSD test ${ }^{\mathrm{e}} \mathrm{P}<0.01$ as compared with the CA group by the MW test. SCRT, Socheongryong-Tang; CA, carrageenan; IF, infiltrated inflammatory cells; LSD, least-significant differences; MW, Mann-Whitney U test. 

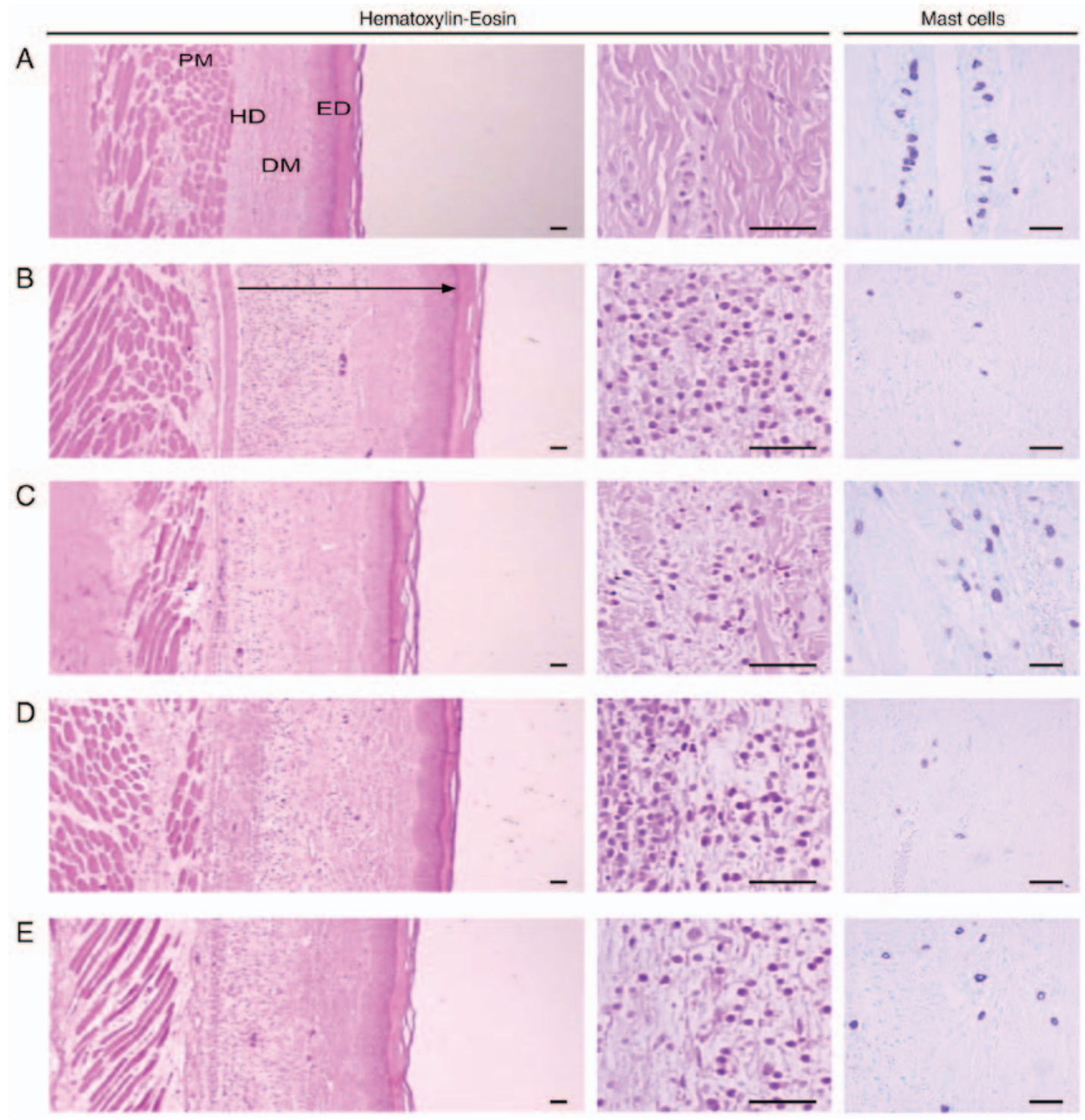

Figure 9. Histological images of the ventral pedis skin. Tissue sections from the ventral pedis of the (A) Control, (B) CA, (C) CA and dexamethasone-treated, (D) CA and SCRT $(0.3 \mathrm{~g} / \mathrm{kg})$-treated and the (E) CA and SCRT $(1.0 \mathrm{~g} / \mathrm{kg})$-treated rats were stained with hematoxylin and eosin or toluidine blue. The arrow indicates the total thickness and scale bars indicate $40 \mu \mathrm{m}$. DM, dermis; ED, epidermis; HD, hypodermis; PM, paw muscle; SCRT, Socheongryong-Tang; LPS, lipopolysaccharide.

in the CA group. Furthermore, the number of infiltrated inflammatory cells in the dorsal and ventral pedis skins at $4 \mathrm{~h}$ after CA injection was increased by 909.09 and 2,244.55\% relative to that in the control group, respectively. The number of infiltrated inflammatory cells in the dorsal pedis skin of rats treated with DEXA and SCRT at $0.3 \mathrm{~g} / \mathrm{kg}$ (low dose) and $1 \mathrm{~g} / \mathrm{kg}$ (high dose) was decreased by 60.78, 10.33 and $39.92 \%$, and that in the ventral pedis skin was decreased by 58.32, 12.84 and $29.31 \%$ compared with that in the CA group, respectively. Finally, the number of mast cells in the dorsal and ventral pedis skin in the CA group was decreased by 66.67 and $65.71 \%$ relative to that in the control group, respectively. In addition, the number of mast cells in the dorsal pedis skins of rats treated with DEXA and SCRT at $0.3 \mathrm{~g} / \mathrm{kg}$ (low dose) and $1 \mathrm{~g} / \mathrm{kg}$ (high dose) was changed by 106.19, 15.46 and $110.31 \%$, and that in the ventral pedis skin was changed by $131.67,-8.33$ and $71.67 \%$ compared with that in the CA group, respectively (Table II).

\section{Discussion}

Although the exact molecular mechanisms associated with herbal medicines have remained to be fully elucidated, herbal medications have been widely used for centuries and have become attractive therapeutics due to fewer side-effects than certain pharmaceutical drugs. In traditional Korean medicine, SCRT has been commonly used to treat a variety of inflammatory allergic diseases, including allergic rhinitis and bronchial asthma (1-3). However, only few studies have provided a scientific assessment of the benefits of SCRT. Accordingly, the present study investigated the influences of SCRT on inflammatory responses of RAW 264.7 cells and rats.

Inflammation has a key role in health as well as in disease. Specifically, it is a response of the body to injury linked to harmful chemical or physical stimuli and microbiological toxins that is involved in multiple pathologies, including arthritis, asthma, inflammatory bowel diseases and 
atherosclerosis. The inflammatory response is intended to demolish or inactivate invading organisms and set the stage for tissue repair (6). NO produced by NOS is associated with the development of inflammation after CA administration, and NO generated by iNOS is associated with the maintenance of the inflammatory responses (24). Increases of iNOS activity that influences inflammatory agents, including endotoxin, interferon- $\gamma$, IL-1 $\beta$ and TNF- $\alpha$, may cause shock and inflammatory responses in humans $(25,26)$. Furthermore, it has been reported that COX-2 is activated during the inflammatory response to produce $\mathrm{PGE}_{2}$, which contributes to the formation of tumors by inhibiting apoptosis and inducing cell division, cancer metastasis and angiogenesis (27). In the present study, SCRT significantly inhibited the LPS-stimulated NO production and expression of iNOS protein in RAW 264.7 cells. Furthermore, the $\mathrm{PGE}_{2}$ assay and immunoblot analysis revealed that SCRT significantly blocked the induction of $\mathrm{PGE}_{2}$ and COX-2 protein by LPS. In paw tissues, treatment with CA resulted in significantly increased expression of iNOS and COX-2 protein in comparison with the control group. However, DEXA significantly decreased the expression of iNOS and COX-2 protein. SCRT $(1 \mathrm{~g} / \mathrm{kg})$ also significantly inhibited the expression of iNOS and COX-2 protein. These results may indirectly suggest that the therapeutic effects of SCRT on various inflammatory symptoms of allergic rhinitis and bronchial asthma are partly due to inhibition of $\mathrm{NO}$ and $\mathrm{PGE}_{2}$ production as well as expression of iNOS and COX-2 protein. TNF- $\alpha$, IL- $1 \beta$ and IL- 6 are frequently encountered pro-inflammatory cytokines that are involved in the interaction with various target cells as well as diverse immunological functions (12-14). These cytokines also mediate immunity and inflammation. Large amounts of TNF- $\alpha$, IL-1 $\beta$ and IL- 6 are released by LPS in macrophages. NF- $\mathrm{KB}$ is also known have a key role in transmitting proinflammatory cytokine signals to the nucleus (13). Treatment with SCRT significantly inhibited the production of these cytokines, suggesting that SCRT inhibits the expression of these specific genes associated with the inflammatory process. The present results demonstrated that SCRT is a strong inhibitor of the production of IL-1 $\beta$, IL-6 and TNF- $\alpha$. Furthermore, the inhibitory mechanism of SCRT on pro-inflammatory cytokines may indicate an important strategy to limit pathological inflammation.

$\mathrm{NF}-\mathrm{KB}$ is a typical transcription factor that controls the expression of genes associated with apoptosis, immune responses and the cell cycle. Unsuitable NF- $\mathrm{kB}$ activation may mediate tumorigenesis and inflammation. However, suppression of NF- $\mathrm{KB}$ activity should be useful in the treatment and prevention of cancer (28). The present study demonstrated that SCRT significantly prevented LPS-stimulated NF- $\kappa B$ activation. It has been suggested that NF- $\mathrm{\kappa B}$ is associated with the regulation of COX-2 and iNOS protein expression, and that several chemopreventive phytochemicals inhibited $\mathrm{COX}-2$ and iNOS protein expression by suppressing NF- $\mathrm{kB}$ activation $(20,29)$. In addition, the NF- $\kappa \mathrm{B}$ pathway is a major regulator of LPS-induced pro-inflammatory cytokine release (30). The present results revealed that LPS increased the levels of p-I- $\kappa \mathrm{B} \alpha$ and NF- $\kappa \mathrm{B}$ (p65), whereas treatment with SCRT resulted in reduced $\mathrm{p}-\mathrm{I}-\mathrm{\kappa} \mathrm{B} \alpha$ levels and inhibited the nuclear translocation of NF-кB. Taken together, these results indicate that suppression of NF- $\kappa B$ activation by SCRT was correlated with inhibition of induction of iNOS, COX-2 and pro-inflammatory cytokines by SCRT. Furthermore, MAPKs, a family of protein threonine/serine kinases, represent a major component of intracellular signaling $(31,32)$. LPS has been reported to induce macrophages, leading to increased activation and phosphorylation of JNK, ERK1/2 and p38 (33). In the present study, it was demonstrated that SCRT $(1 \mathrm{mg} / \mathrm{ml})$ significantly suppressed the phosphorylation of JNK and ERK1/2, whereas the phosphorylation of p38 was unaffected. Furthermore, the results of the present demonstrated an association between inhibited phosphorylation of JNK and ERK1/2 and inactivation of NF- $\kappa \mathrm{B}$. Therefore, the aforementioned data suggests that the anti-inflammatory activities of SCRT may be due to inhibition of LPS-stimulated activation of NF-kB and phosphorylation of JNK and ERK1/2 in vitro.

Local treatment with CA induces severe acute edematous inflammation, and a variety of inflammatory mediators produced from resident macrophages, damaged tissues, polymorphonuclear cells (e.g., neutrophils) and mast cells are involved in the associated pathogenesis (34-37). Histopathologically, infiltration of inflammatory cells and loosening of connective tissues were observed around CA-treated sites (38-40). Thus, the present study used CA-induced paw edema as a representative model to assess the anti-inflammatory activities of therapeutic candidates $(20-23,37,41,42)$, while the in vivo and in vitro models may exhibit differences of major cell types. In the present study, prominent increases of inflammatory infiltrated cells with increases in skin thicknesses on the dorsal and ventral pedis were observed following treatment of rat paw skins with CA. However, the CA-induced acute edematous inflammation was significantly inhibited by treatment with the higher dosage of SCRT and DEXA $(\mathrm{P}<0.01)$. In rats treated with the lower dose of SCRT, a significant decrease in the dorsal pedis skin thickness relative to that in the CA group was demonstrated, but no significant changes in the ventral pedis skin thicknesses or number of infiltrated inflammatory cells on the dorsal and ventral pedis skin tissues were demonstrated. These results are considered as direct evidence that the higher dosage of SCRT has beneficial antiinflammatory effects sufficient to reduce inflammatory edema and cell infiltration, but that the lower dosage was only effective against edematous changes restricted to dorsal pedis skin tissues but that it was not sufficient to reduce inflammatory cell infiltration and edema in ventral pedis skin tissues. Mast cells are distributed in the body and have an important role in a variety of inflammatory and allergic diseases. These cells also have cell surface immunoglobulin (Ig)E receptors and are provoked by interaction between bound IgE and the pertinent antigen (43). Following activation, mast cells release a variety of bioactive substances, including various lipid mediators and histamine that cause an immediate-type allergic reaction. Mast cell degranulation has been also known to increase in the acute $(44,45)$, as well as the chronic stage (46-48) of diverse inflammatory and allergic diseases. Noticeable increases of mast cell degranulation in dermis tissue have been observed in CA-induced acute inflammation, and the inhibition of these mast cell activities (degranulation) has been used as a beneficial index to predict the efficacy of anti-inflammatory drugs $(34,49,50)$. In the present study, treatment with the higher dosage of SCRT and DEXA markedly and significantly 
inhibited mast cell degranulation and maintained the mast cell numbers in the dermis of the $\mathrm{CA}$-induced rats $(\mathrm{P}<0.01)$, but no significant changes in mast cell numbers were observed in rats treated with the lower dosage of SCRT compared with those in the CA group on the dorsal and ventral pedis skins. These results provide direct evidence that the higher dosage of SCRT exerted anti-inflammatory effects through the control of mast cell activation, as indicated by at least partial degranulation, but that the lower dosage of SCRT did not. Furthermore, as the results of the toluidine blue staining of edematous tissues indicated that SCRT inhibited the numbers of degranulated mast cells, SCRT may have therapeutic potential to reduce type I hypersensitivity. In the present in vivo study, rats were injected with CA once, without any previous injection of any sensitizing agent, so that hypersensitivity could not be assessed. As previously established, CA injection causes a maximum increase in paw volumes within $4 \mathrm{~h}$, and in the present study, paw volumes were monitored at 1-h time intervals for $4 \mathrm{~h}$. Thus, the effect of SCRT on type IV hypersensitivity reactions could also not be determined.

SCRT is an extract from a blend of 8 medicinal herbs. Several active components of SCRT have been reported to exert anti-inflammatory activities. Ephedrine and pseudoephedrine are stereoisomers isolated from the plant Ephedra sinica (Ephedraceae family) or the traditional Chinese medicinal herb Ma Huang (51). These compounds have also been reported to exert powerful anti-inflammatory effects against D-galactosamine/LPS-stimulated acute liver failure in rats (52). Furthermore, ephedrine and pseudoephedrine were reported to suppress $\mathrm{CA}$-induced hind paw edema in mice. Hind paw edema stimulated by prostaglandin E, histamine and bradykinin was reported to be inhibited by these compounds, demonstrating that they exert anti-inflammatory effects (53). Paeoniflorin has pharmacological properties, including anti-inflammatory and immunomodulatory effects, as well as the ability to suppress rheumatic diseases (18). In addition, Liu et al (54) reported that paeoniflorin reduced 1-methyl-4-phenyl-1,2,3,6-tetrahydropyridine-induced toxicity by suppression of neuroinflammation via activation of adenosine A1 receptor, and that paeoniflorin may be a useful neuroprotective compound for the treatment of Parkinson's disease. Cinnamic acid was reported to have significant antiinflammatory activities in vitro and in vivo (55). Furthermore, this compound acts as a lipoxygenase inhibitor with antioxidant, anti-inflammatory and anticancer activity $(56,57)$. Glycyrrhizin, a triterpene glycoside from the roots of licorice, resulted in widely inhibited induction of inflammatory mediators stimulated by CpG-DNA in RAW 264.7 cells, as well as attenuated inflammatory responses stimulated by toll-like receptor (TLR)3 and TLR4 (58). In addition, inhibition of NF- $\kappa$ B activity and IL-8 production in lung cells and attenuation of CA-induced lung damage in mice by glycyrrhizin have been demonstrated $(59,60)$. Gomisin A inhibits the activation of $\mathrm{NF}-\kappa \mathrm{B}$ and oxidative stress, leading to the suppression of pro-inflammatory mediators by attenuating $\mathrm{CCl}_{4}$-stimulated acute liver damage (61). Furthermore, gomisin A was reported to have neuroprotective effects by relieving the microglia-mediated neuroinflammatory response through inhibition of TLR4-mediated MAPKs and NF- $\mathrm{B}$ signaling pathways (62). UPLC analysis revealed that the major active components of SCRT are ephedrine, paeoniflorin, cinnamic acid, glycyrrhizin and gomisin-A. Accordingly, it is suggested that the anti-inflammatory properties of SCRT on LPS-stimulated RAW 264.7 cells and CA-induced rat paw edema may be due to the action of these 5 compounds.

In conclusion, the present results clearly demonstrated that SCRT has anti-inflammatory activities through decreasing the production of inflammatory mediators, including $\mathrm{PGE}_{2}, \mathrm{NO}$ and pro-inflammatory cytokines via inhibition of the signaling pathways of JNK, ERK1/2 and NF- $\mathrm{BB}$ in the LPS-stimulated RAW 264.7 cells. In addition, the results from the CA-induced paw edema model demonstrated an anti-edema effect of SCRT. Furthermore, SCRT $(1 \mathrm{~g} / \mathrm{kg})$ inhibited acute edematous inflammation through inhibition of mast cell degranulation and infiltration of inflammatory cells. Therefore, the present study provided scientific evidence for the anti-inflammatory activities of SCRT.

\section{Acknowledgements}

This study was supported by the Basic Science Research Program through the National Research Foundation of Korea (NRF) funded by the Ministry of Education (grant no. NRF-2015 R1D1A1A01059994) and by the NRF grant funded by the Korean Government (Ministry of Science, ICT and Future Planning; grant no. 2012 R1A5A2A42671316).

\section{Competing interests}

The authors declare that they have no competing interests.

\section{References}

1. Kao ST, Lin CS, Hsieh CC, Hsieh WT and Lin JG: Effects of Xiao-Qing-Long-Tang (XQLT) on bronchoconstriction and airway eosinophil infiltration in ovalbumin-sensitized guinea pigs: In vivo and in vitro studies. Allergy 56: 1164-1171, 2001.

2. Ko E, Rho S, Cho C, Choi H, Ko S, Lee Y, Hong MC, Shin MK, Jung SG and Bae H: So-Cheong-Ryong-Tang, traditional Korean medicine, suppresses Th2 lineage development. Biol Pharm Bull 27: 739-743, 2004.

3. Ko E, Rho S, Lee E, Seo Y, Cho C, Lee Y, Min BI, Shin MK, Hong MC and Bae H: Traditional Korean medicine (SCRT) modulate Th1/Th2 specific cytokine production in mice $\mathrm{CD}^{+} \mathrm{T}$ cell. J Ethnopharmacol 92: 121-128, 2004.

4. Nakao M, Muramoto Y, Hisadome M, Yamano N, Shoji M, Fukushima Y, Saruwatari J and Nakagawa K: The effect of Shoseiryuto, a traditional Japanese medicine, on cytochrome $\mathrm{P} 450 \mathrm{~s}, \mathrm{~N}$-acetyltransferase 2 and xanthine oxidase, in extensive or intermediate metabolizers of CYP2D6. Eur J Clin Pharmacol 63: 345-353, 2007.

5. Lawrence T, Willoughby DA and Gilroy DW: Anti-inflammatory lipid mediators and insights into the resolution of inflammation. Nat Rev Immunol 2: 787-795, 2002.

6. Guzik TJ, Korbut R and Adamek-Guzik T: Nitric oxide and superoxide in inflammation and immune regulation. J Physiol Pharmacol 54: 469-487, 2003.

7. Nathan C: Nitric oxide as a secretory product of mammalian cells. FASEB J 6: 3051-3064, 1992.

8. MacMicking J, Xie QW and Nathan C: Nitric oxide and macrophage function. Annu Rev Immunol 15: 323-350, 1997.

9. Nagy G, Clark JM, Buzás EI, Gorman CL and Cope AP: Nitric oxide, chronic inflammation and autoimmunity. Immunol Lett 111: 1-5, 2007.

10. Botting RM: Cyclooxygenase: Past, present and future. A tribute to John R. Vane (1927-2004). J Therm Biol 31: 208-219, 2006.

11. Blobaum AL and Marnett LJ: Structural and functional basis of cyclooxygenase inhibition. J Med Chem 50: 1425-1441, 2007. 
12. Delgado AV, McManus AT and Chambers JP: Production of tumor necrosis factor-alpha, interleukin 1-beta, interleukin 2, and interleukin 6 by rat leukocyte subpopulations after exposure to substance P. Neuropeptides 37: 355-361, 2003.

13. Yoshimura A: Signal transduction of inflammatory cytokines and tumor development. Cancer Sci 97: 439-447, 2006.

14. Beutler B and Cerami A: The biology of cachectin/TNF- $\alpha$ primary mediator of the host response. Annu Rev Immunol 7: $625-655,1989$

15. Ghosh $\mathrm{S}$ and Ksarin M: Missing pieces in the NF-kappaB puzzle. Cell 109 (Suppl): S81-S96, 2002.

16. Chan ED and Riches DW: IFN-gamma + LPS induction of iNOS is modulated by ERK, JNK/SAPK, and p38 (mapk) in a mouse macrophage cell line. Am J Physiol Cell Physiol 280: C441-C450, 2001.

17. Nagai T, Arai Y, Emori M, Nunome SY, Yabe T, Takeda T and Yamada H: Anti-allergic activity of a Kampo (Japanese herbal) medicine 'Sho-seiryu-to (Xiao-Qing-Long-Tang)' on airway inflammation in a mouse model. Int Immunopharmacol 4 1353-1365, 2004.

18. Wang SD, Lin LJ, Chen CL, Lee SC, Lin CC, Wang JY and Kao ST: Xiao-Qing-Long-Tang attenuates allergic airway inflammation and remodeling in repetitive Dermatogoides pteronyssinus challenged chronic asthmatic mice model. J Ethnopharmacol 142: 531-538, 2012.

19. Kao ST, Wang SD, Wang JY, Yu CK and Lei HY: The Effect of herbal medicine, xiao-qing-long-tang (XQLT), on allergeninduced bronchial inflammation in mite-sensitized mice. Allergy 55: 1127-1130, 2000

20. Kim YW, Zhao RJ, Park SJ, Lee JR, Cho IJ, Yang CH, Kim SG and Kim SC: Anti-inflammatory effects of liquiritigenin as a consequence of the inhibition of NF-kappaB-dependent iNOS and pro-inflammatory cytokines production. Br J Pharmacol 154 165-173, 2008.

21. Lee CW, Park SM, Kim YS, Jegal KH, Lee JR, Cho IJ, Ku SK, Lee JY, Ahn YT, Son Y, et al: Biomolecular evidence of antiinflammatory effects by Clematis mandshurica Ruprecht root extract in rodent cells. J Ethnopharmacol 155: 1141-1155, 2014.

22. Lee CW, Park SM, Zhao R, Lee C, Chun W, Son Y, Kim SH, Jung JY, Jegal KH, Cho IJ, et al: Hederagenin, a major component of Clematis mandshurica Ruprecht root, attenuates inflammatory responses in RAW 264.7 cells and in mice. Int Immunopharmacol 29: 528-537, 2015

23. Kim SY, Park SM, Hwangbo M, Lee JR, Byun SH, Ku SK, Cho IJ, Kim SC, Jee SY and Park SJ: Cheongsangbangpung-tang ameliorated the acute inflammatory response via the inhibition of NF- $\kappa \mathrm{B}$ activation and MAPK phosphorylation. BMC Complement Altern Med 17: 46, 2017.

24. Borthakur A, Bhattacharyya S, Dudeja PK and Tobacman JK Carrageenan induces interleukin-8 production through distinct Bcl10 pathway in normal human colonic epithelial cells. Am J Physiol Gastrointest Liver Physiol 292: G829-G838, 2007.

25. Szabó C: Alterations in nitric oxide production in various forms of circulatory shock. New Horiz 3: 2-32, 1995.

26. Southan GJ and Szabó C: Selective pharmacological inhibition of distinct nitric oxide synthase isoforms. Biochem Pharmacol 51 383-394, 1996

27. Gröesch S, Maier TJ, Schiffmann S and Geisslinger G: Cyclooxygenase-2 (COX-2)-independent anticarcinogenic effects of selective COX-2 inhibitors. J Natl Cancer Inst 98: 736-747, 2006.

28. Aggarwal BB: Nuclear factor-kappaB: The enemy within. Cancer Cell 6: 203-208, 2004

29. Surh YJ, Chun KS, Cha HH, Han SS, Keum YS, Park KK and Lee SS: Molecular mechanisms underlying chemopreventive activities of anti-inflammatory phytochemicals: Down-regulation of COX-2 and iNOS through suppression of NF-kappa B activation. Mutat Res 480-481:243-268, 2001

30. Lappas M, Permezel M, Georgiou HM and Rice GE: Nuclear factor kappa B regulation of pro-inflammatory cytokines in human gestational tissues in vitro. Biol Reprod 67: 668-673, 2002.

31. Guha M and Mackman N: LPS induction of gene expression in human monocytes. Cell Signal 13: 85-94, 2001

32. Xiao ZY, Zhou WX, Zhang YX, Cheng JP, He JF, Yang RF and Yun LH: Inhibitory effect of linomide on lipopolysaccharideinduced proinflammatory cytokine tumor necrosis factor-alpha production in RAW264.7 macrophages through suppression of NF-kappaB, p38, and JNK activation. Immunol Lett 114: 81-85, 2007.
33. Choi MS, Lee SH, Cho HS, Kim Y, Yun YP, Jung HY, Jung JK, Lee BC, Pyo HB and Hong JT: Inhibitory effect of obovatol on nitric oxide production and activation of NF-kappaB/MAP kinases in lipopolysaccharide-treated RAW 264.7 cells. Eur J Pharmacol 556: 181-189, 2007.

34. Mazzari S, Canella R, Petrelli L, Marcolongo G and Leon A: $\mathrm{N}$-(2-hydroxyethyl)hexadecanamide is orally active in reducing edema formation and inflammatory hyperalgesia by downmodulating mast cell activation. Eur J Pharmacol 300: 227-236, 1996.

35. Antonio MA and Souza Brito AR: Oral anti-inflammatory and anti-ulcerogenic activities of a hydroalcoholic extract and partitioned fractions of Turnera ulmifolia (Turneraceae). J Ethnopharmacol 61: 215-228, 1998.

36. Handy RL and Moore PK: A comparison of the effects of L-NAME, 7-NI and L-NIL on carrageenan-induced hind paw oedema and NOS activity. Br J Pharmacol 123: 1119-1126, 1998.

37. Gupta M, Mazumder UK, Gomathi $P$ and Selvan VT: Antiinflammatory evaluation of leaves of Plumeria acuminate. BMC Complement Altern Med 6: 36, 2006.

38. Holt S, Comelli F, Costa B and Fowler CJ: Inhibitors of fatty acid amide hydrolase reduce carrageenan-induced hind paw inflammation in pentobarbital-treated mice: Comparison with indomethacin and possible involvement of cannabinoid receptors. Br J Pharmacol 146: 467-476, 2005.

39. Liu J, Zhang W, Zhou L, Wang X and Lian Q: Anti-inflammatory effect and mechanism of osthole in rats. Zhong Yao Cai 28: 1002-1006, 2005

40. Beloeil H, Ababneh Z, Chung R, Zurakowski D, Mulkern RV and Berde CB: Effects of bupivacaine and tetrodotoxin on carrageenan-induced hind paw inflammation in rats (Part 1): Hyperalgesia, edema, and systemic cytokines. Anesthesiol 105: 128-138, 2006

41. Lee JH, Choi YH and Choi BT: The anti-inflammatory effects of $2 \mathrm{~Hz}$ electroacupuncture with different intensities on acute carrageenan-induced inflammation in the rat paw. Int $\mathrm{J}$ Mol Med 16: 99-102, 2005.

42. Rao CV, Verma AR, Gupta PK and Vijayakumar M: Antiinflammatory and anti-nociceptive activities of Fumaria indica whole plant extract in experimental animals. Acta Pharm 57: 491-498, 2007.

43. Holgate ST: The role of mast cells and basophils in inflammation. Clin Exp Allergy 30 (Suppl 1): S28-S32, 2000.

44. Crimi E, Chiaramondia M, Milanese M, Rossi GA and Brusasco V: Increased numbers of mast cells in bronchial mucosa after the late-phase asthmatic response to allergen. Am Rev Respir Dis 144: 1282-1286, 1991.

45. Gauvreau GM, Lee JM, Watson RM, Irani AM, Schwartz LB and O'Byrne PM: Increased numbers of both airway basophils and mast cells in sputum after allergen inhalation challenge of atopic asthmatics. Am J Respir Crit Care Med 161: 1473-1478, 2000.

46. Mitchell EB, Crow J, Williams G and Platts-Mills TA: Increase in skin mast cells following chronic house dust mite exposure. $\mathrm{Br}$ J Dermatol 114: 65-73, 1986.

47. Chanez P, Lacoste JY, Guillot B, Giron J, Barnéon G, Enander I, Godard P, Michel FB and Bousquet J: Mast cells' contribution to the fibrosing alveolitis of the scleroderma lung. Am Rev Respir Dis 147: 1497-1502, 1993.

48. Armbrust T, Batusic D, Ringe B and Ramadori G: Mast cells distribution in human liver disease and experimental rat liver fibrosis. Indications for mast cell participation in development of liver fibrosis. J Hepatol 26: 1042-1054, 1997.

49. Weischer $\mathrm{CH}$ : Experimental studies on the possibility of influencing mast cells in experimental carrageenin-induced rat paw edema: Histological study on the effects of some non-steroidal anti-inflammatory agents (author's transl). Arzneimittelforschung 26: 1867-1870, 1976 (In German).

50. Sin YM, Sedgwick AD, Chea EP and Willoughby DA: Mast cells in newly formed lining tissue during acute inflammation: A six day air pouch model in the mouse. Ann Rheum Dis 45: 873-877, 1986.

51. Mehendale SR, Bauer BA and Yuan CS: Ephedra-containing dietary supplements in the US versus ephedra as a Chinese medicine. Am J Chin Med 32: 1-10, 2004.

52. Wu Z, Kong X, Zhang T, Ye J, Fang Z and Yang X: Pseudoephedrine/ephedrine shows potent anti-inflammatory activity against TNF- $\alpha$-mediated acute liver failure induced by lipopolysaccharide/D-galactosamine. Eur J Pharmacol 724: 112-121, 2014. 
53. Kasahara Y, Hikino H, Tsurufuji S, Watanabe M and Ohuchi K: Anti-inflammatory actions of ephedrines in acute inflammations. Planta Med: 325-331, 1985.

54. Liu HQ, Zhang WY, Luo XT, Ye Y and Zhu XZ: Paeoniflorin attenuates neuroinflammation and dopaminergic neurodegeneration in the MPTP model of Parkinson's disease by activation of adenosine A1 receptor. Br J Pharmacol 148: 314-325, 2006.

55. Liao JC, Deng JS, Chiu CS, Hou WC, Huang SS, Shie PH and Huang GJ: Anti-inflammatory activities of Cinnamomum cassia constituents in vitro and in vivo. Evid Based Complement Alternat Med 2012: 429320, 2012.

56. Liu L, Hudgins WR, Shack S, Yin MQ and Samid D: Cinnamic acid: A natural product with potential use in cancer intervention. Int J Cancer 62: 345-350, 1995.

57. Hadjipavlou-Litina D and Pontiki E: Aryl-acetic and cinnamic acids as lipoxygenase inhibitors with antioxidant, anti-inflammatory, and anticancer activity. Methods Mol Biol 1208: 361-377, 2015.

58. Schröfelbauer B, Raffetseder J, Hauner M, Wolkerstorfer A, Ernst W and Szolar OH: Glycyrrhizin, the main active compound in liquorice, attenuates pro-inflammatory responses by interfering with membrane-dependent receptor signaling. Biochem J 421: 473-482, 2009.
59. Takei H, Baba Y, Hisatsune A, Katsuki H, Miyata T, Yokomizo K and Isohama Y: Glycyrrhizin inhibits interleukin-8 production and nuclear factor-kappa B activity in lung epithelial cells, but not through glucocorticoid receptors. J Pharmacol Sci 106: 460-468, 2008.

60. Menegazzi M, Di Paola R, Mazzon E, Genovese T, Crisafulli C, Dal Bosco M, Zou Z and Suzuki H: Glycyrrhizin attenuates the development of carrageenan-induced lung injury in mice. Pharmacol Res 58: 22-31, 2008.

61. Teraoka R, Shimada T and Aburada M: The molecular mechanisms of the hepatoprotective effect of gomisin A against oxidative stress and inflammatory response in rats with carbon tetrachloride-induced acute liver injury. Biol Pharm Bull 35: 171-177, 2012.

62. Wang X, Hu D, Zhang L, Lian G, Zhao S, Wang C, Yin J, Wu C and Yang J: Gomisin A inhibits lipopolysaccharide-induced inflammatory responses in N9 microglia via blocking the NF-кB/MAPKs pathway. Food Chem Toxicol 63: 119-127, 2014. 